Portland State University

PDXScholar

Fall 1-1-2012

\title{
The Effects of Hypoxia and Temperature on Developing Embryos of the Annual Killifish Austrofundulus limnaeus
}

Skye N. Anderson

Portland State University

Follow this and additional works at: https://pdxscholar.library.pdx.edu/open_access_etds

Part of the Aquaculture and Fisheries Commons, Developmental Biology Commons, and the Other Physiology Commons

Let us know how access to this document benefits you.

\section{Recommended Citation}

Anderson, Skye N., "The Effects of Hypoxia and Temperature on Developing Embryos of the Annual Killifish Austrofundulus limnaeus" (2012). Dissertations and Theses. Paper 888.

https://doi.org/10.15760/etd.888

This Thesis is brought to you for free and open access. It has been accepted for inclusion in Dissertations and Theses by an authorized administrator of PDXScholar. Please contact us if we can make this document more accessible: pdxscholar@pdx.edu. 
The Effects of Hypoxia and Temperature on Developing Embryos of the Annual Killifish Austrofundulus limnaeus

\author{
by
}

Skye N. Anderson

A thesis submitted in partial fulfillment of the requirements for the degree of

Master of Science

in

Biology

Thesis Committee:

Jason E. Podrabsky, Chair

Stanley Hillman

Sarah Eppley

Portland State University

2012 
(C) 2012 Skye N. Anderson 
Abstract

Little is known about the physiology or biochemistry of hypoxia (reduced levels of oxygen) tolerance during development in vertebrate embryos. In most species, relatively brief bouts of severe hypoxia are lethal or teratogenic. An exception to such hypoxia intolerance is the annual killifish Austrofundulus limnaeus, in which populations persist in hypoxic environments. This species inhabits seasonal ponds in Venezuela, surviving through the dry season in the form of diapausing embryos. Embedded in the pond sediment, embryos of $A$. limnaeus are routinely exposed to hypoxia and anoxia (lack of oxygen) as part of their normal development. Here, we exposed embryos to various levels of $\mathrm{PO}_{2}$ $(21.2,15.6,10.8,8.4,6.1,3.6$, and $2.2 \mathrm{kPa})$ at two different temperatures $\left(25^{\circ} \mathrm{C}\right.$ and $30^{\circ} \mathrm{C}$ ) to study the effects on developmental rate and heart rate. We also measured enzyme activity and quantified DNA content of individual embryos to compare differences among the varying levels of hypoxia and temperature. Hypoxia caused a significant decline in developmental rate and caused a stagespecific decline in heart rate. Higher temperature caused an increase in the developmental rate for those embryos incubated at $\mathrm{PO}_{2}$ of $6.1 \mathrm{kPa}$ and greater. Temperature had a negative effect by hindering development below a $\mathrm{PO}_{2}$ of 6.1 $\mathrm{kPa}$. Total embryonic DNA content was reduced at low partial pressures (15.6, $10.8,8.4,6.1,3.6$, and $2.2 \mathrm{kPa}$ ) of oxygen. Citrate synthase, lactate 
dehydrogenase, and phosphoenolpyruvate carboxykinase were all down-

regulated indicating a complete lack of enzymatic metabolic compensation to combat reduced oxygen levels. 


\section{Dedication}

This thesis is dedicated to my grandma, Marilynn Nussbaum. 
Copious thanks goes to Jason Podrabsky for endless encouragement and enthusiasm throughout my research project and teaching. A big thanks goes to Stanley Hillman, Ed DeGrauw, and Jason Podrabsky for the amazing support and feedback I received, which helped me recognize options that surrounded me during my graduate career. I give much appreciation and thanks to Keith Galbraith for the dedicated personal support he gave to the success of my project, graduate work and ultimately to my career. In addition, my family provided personal support as well as financial support, which I am truly grateful for. Finally, I express gratitude to The Henton Family for the much-needed social support, interest in my work, and encouragement throughout the whole process. 


\section{Table of Contents}

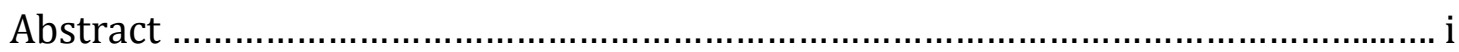

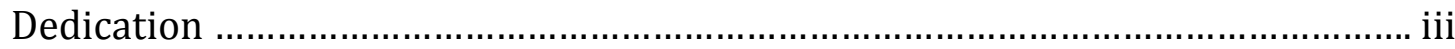

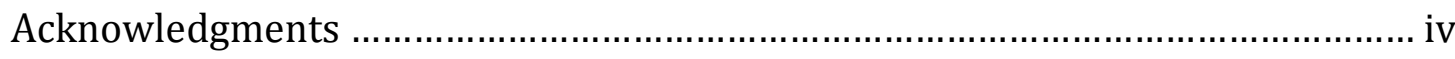

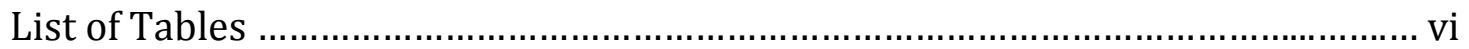

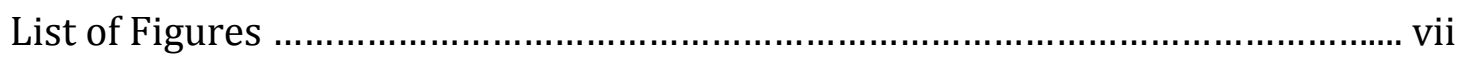

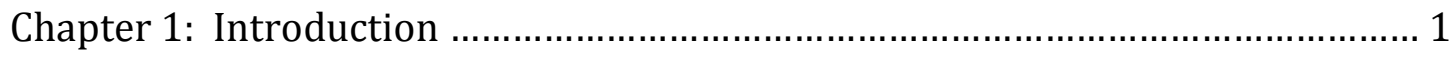

Materials and Methods ................................................................... 5

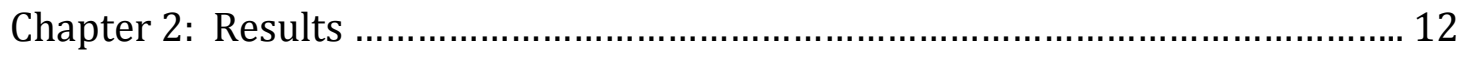

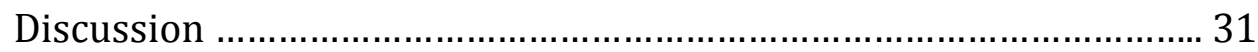

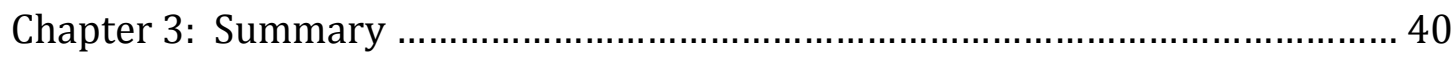

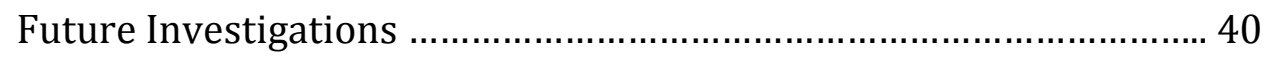

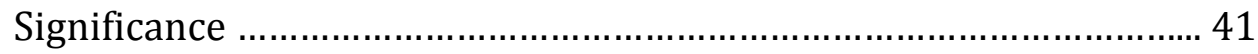

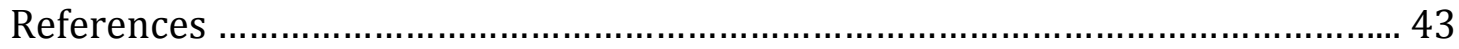




\section{List of Tables}

Table 1. Results of Two-way ANOVA with Bonferroni corrected post hoc tests to compare average time to reach each development stage

Table 2. Results of Two-way ANOVA with Bonferroni corrected post hoc tests

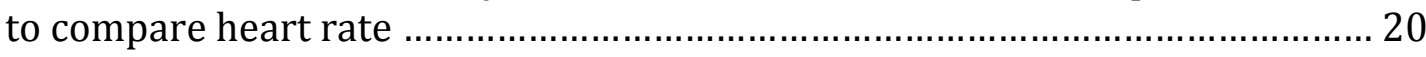




\section{List of Figures}

Figure 1. Developmental progression expressed as Wourms' stage as a function of developmental time 14

Figure 2. Average time in days to reach each developmental stage 15

Figure 3. Heart rate (bpm) as a function of days post-fertilization 17

Figure 4. Heart rate (bpm) relative to developmental stage 18

Figure 5. DNA quantity at the completion of development 21

Figure 6. The enzymatic capacity for citrate synthase activity expressed per gram of tissue at the completion of development

Figure 7. The enzymatic capacity for citrate synthase activity expressed per gram of DNA at the completion of development

Figure 8. The enzymatic capacity for lactate dehydrogenase activity expressed per gram of tissue at the completion of development

Figure 9. The enzymatic capacity for lactate dehydrogenase activity expressed per gram of DNA at the completion of development

Figure 10. The enzymatic capacity for phosphoenolpyruvate carboxykinase activity expressed per gram of tissue at the completion of development

Figure 11. The enzymatic capacity for phosphoenolpyruvate carboxykinase Activity expressed per gram of DNA at the completion of development 


\section{Chapter 1}

\section{Introduction}

The annual killifish Austrofundulus limnaeus is endemic to South America and is predominately found in the Maracaibo basin of Venezuela (Hrbek et al., 2005). This species inhabits seasonal ponds in areas that experience pronounced dry and rainy seasons. While adult and juvenile fish flourish throughout the rainy season they cannot survive the drying of the ponds (Myers, 1952). Developing embryos, on the other hand, can survive through this dry season by entering diapause, a period of suspended embryonic development that increases resistance to unfavorable environmental conditions (Machado and Podrabsky, 2007; Myers, 1952; Podrabsky et al., 2001; Podrabsky and Hand, 1999;

Podrabsky et al., 2007; Podrabsky et al., 2012; Wourms, 1972). During both the dry and rainy season, embryos of this species are buried in the pond sediment and are likely routinely exposed to hypoxia $\left(\right.$ low $\left.\mathrm{PO}_{2}\right)$ and anoxia $\left(\mathrm{PO}_{2}=0\right)$ as part of their normal development (Podrabsky et al., 1998). During the rainy season, $\mathrm{O}_{2}$ flux is decreased by microbial activity in the inundated soils decreasing the driving force for $\mathrm{O}_{2}$ diffusion. During the dry season, $\mathrm{O}_{2}$ flux is decreased by decreasing tissue diffusion capacity with the physiological mechanisms employed by the embryos to retain water and avoid dehydration (Podrabsky et al., 2001). When the rainy season returns, ponds refill with water 
and environmental $\mathrm{PO}_{2}$ is thought to be a major cue that induces hatching of killifish embryos to repopulate the pond continuing the lifecycle (DiMichele and Powers, 1984; DiMichele and Taylor, 1980, 1981; Podrabsky and Hand, 1999; Wourms, 1972).

Embryonic diapause is presumably an adaptive mechanism of annual killifish to sustain populations in their naturally variable and seasonal environment. Diapause appears to be an inducible phenotype in A. limnaeus as evidenced by laboratory studies illustrating that an increase in incubation temperature of just $5^{\circ} \mathrm{C}$ from 25 to $30^{\circ} \mathrm{C}$ can cause embryos to bypass diapause II and "escape" dormancy (Podrabsky et al., 2010). The consequences of entering embryonic diapause on the development and physiology of the embryos and resulting adults is minimally understood and is of great interest.

Entering a state of diapause allows embryos to withstand indefinite periods of time with little to no oxygen at a time when oxygen plays a crucial role in the normal development of most other vertebrates. Sufficient amounts of oxygen are required to supply the cardiovascular system, the brain, the nervous system, and organ tissues for proper function and development (FelderhoffMueser et al., 2004; Finn et al., 1995; Rombough, 1988a, b). Vertebrate tissues, especially heart and brain are dependent on oxygen as a terminal electron acceptor in mitochondrial metabolism, the dominant metabolic pathway for ATP production (Lutz, 1992; Lutz and Nilsson, 1997; Lutz et al., 1996; Nilsson and 
Lutz, 2004). Anaerobic pathways do exist, but are limited in capacity to support the high metabolic rates of most vertebrates, and thus are not the preferred metabolic pathways in vertebrate systems, even those with significant hypoxia and anoxia tolerance (Lutz et al., 1996; Nilsson and Lutz, 2004).

Hypoxia or anoxia can have detrimental effects on development in most vertebrate species. Infant monkeys exposed to short bursts (30 min) of hypoxia $\left(\mathrm{PO}_{2}=20-22 \mathrm{Torr}\right.$, or 2.6-2.9 kPa) experienced toxic effects to the nervous system that are thought to cause the development of epilepsy (Sloper et al., 1980). In general, hypoxia exposure in adult vertebrate systems has such consequential effects as cardiovascular impairment and disease, inflammatory disease, diabetes, and cancer (Brahimi-Horn and Pouyssegur, 2007). Most vertebrate embryos have minimal capacity to deal with the detrimental effects of hypoxia. Chicken and frog embryos exhibit developmental abnormalities in the form of impaired early stage development, decreased survival rate, delayed development, developmental anomalies, and early hatching (Altimiras and Phu, 2000; Bradford and Seymour, 1988; Grabowski, 1961).

Most vertebrate species require oxygen to develop functionally and completely; therefore, the ability of A. limnaeus to withstand prolonged periods of hypoxia and anoxia is of interest. While early embryos of $A$. limnaeus are the most anoxia tolerant vertebrates, this exceptional tolerance is lost during development and by the time of hatching they share a sensitivity to hypoxia 
similar to other ectothermic vertebrates (Podrabsky et al., 2012). This study focuses on the effects of $\mathrm{PO}_{2}$ on developmental progression, cardiac function, and metabolic enzyme capacities in embryos of A. limnaeus exposed to a range of oxygen partial pressures during development. In this investigation I propose the following hypotheses: (1) embryos of A. limnaeus incubated at lower oxygen levels will develop more slowly than those incubated at higher oxygen levels; (2) developmental progression will be faster at 25 versus $30^{\circ} \mathrm{C}$; (3) cardiovascular development will be negatively affected in hypoxia-exposed embryos, and; (4) metabolic enzyme activity specific to anaerobic conditions will be up-regulated at reduced partial pressures of oxygen. Investigation of these hypotheses on this species will allow for the identification of mechanisms for survival of hypoxia in a vertebrate system and will hopefully identify the periods of development that are most sensitive to lack of oxygen. Understanding the effects of hypoxia on vertebrate development is crucial to understanding how the developmental environment effects organismal form and function. This is especially relevant as climate change alters the aquatic environments on Earth causing the spread of hypoxic "dead zones" in many coastal ecosystems (Diaz and Rosenberg, 2008). We must strive to understand both the short- and long-term effects that hypoxia may have on development in order to predict outcomes from such exposures. 


\section{Materials and Methods}

The effects of hypoxia on developmental progression and heart rate

To investigate the effects of hypoxia and temperature on embryonic development of Austrofundulus limnaeus, we exposed embryos to seven different partial pressures of oxygen, 21.2, 15.6, 10.8, 8.4, 6.1, 3.6, and $2.2 \mathrm{kPa}$, at two different temperatures, $25^{\circ} \mathrm{C}$ and $30^{\circ} \mathrm{C}$. Embryos were collected from 42 spawning pairs of adult fish in two separate rack systems as previously described (Machado and Podrabsky, 2007; Podrabsky, 1999). These adult fish were raised as embryos at $25 \pm 1^{\circ} \mathrm{C}$, and as larvae and adults at $26 \pm 1^{\circ} \mathrm{C}$. Embryos were collected within $2 \mathrm{hr}$ following fertilization (2-4 cell-stage embryos) and were randomly divided into 14 different petri dishes (seven per temperature). Exposure to hypoxia was accomplished using a Bactrox hypoxic chamber (Sheldon Laboratories, Cornelius, OR) that can control oxygen partial pressure by mixing atmospheric air with industrial grade high-pressure nitrogen gas (Matheson Inc.). The chamber was initially set at atmospheric levels of oxygen and then the partial pressure was decreased in a step-wise fashion during the day allowing at least $30 \mathrm{~min}$ for the level of oxygen to equilibrate within the chamber once the set point was reached. The chamber moved between set points within 10-20 min, with lower partial pressures taking longer to achieve. At the end of each day the chamber was left at the last oxygen partial pressure achieved, and thus every other day the chamber was at either 2.2 or $21.2 \mathrm{kPa}$ for the start of 
observations. This schedule eliminated any systematic effects in developmental staging and progression due to the time of day the embryos were observed across the different oxygen treatments. Embryo medium (Podrabsky, 1999) was equilibrated to the appropriate $\mathrm{PO}_{2}$ by pumping chamber air through the medium with a standard aquarium air pump for at least 30 min after the chamber had reached the appropriate set point. The temperature of the embryo medium was controlled at $30^{\circ} \mathrm{C}$ by placing it in the built-in incubator set to $30^{\circ} \mathrm{C}$ contained within the Bactrox chamber. A temperature of $25^{\circ} \mathrm{C}$ was achieved by using the chamber working area which remained at $25 \pm 1^{\circ} \mathrm{C}$. The embryo medium was changed each time the embryos were observed (daily) and the petri dishes were sealed in $550 \mathrm{ml}$ polypropylene plastic containers (Lock n Lock) fitted with airtight (rubber gasket sealed) lids at their respective oxygen level and temperature. Preliminary experiments confirmed that the oxygen levels were constant in the containers for at least 24 hours.

Embryos were observed daily for the first 85 days of the experiment, or until they had completed development and been in diapause III for 11 days. For those embryos that required greater than 85 days to complete development, they were observed every other day from 85 days until they were at stage 43 for 11 days (Stage 43). The maximum time for developmental observations was 104 days. Embryos were staged at every observation according to Wourms (1972). When possible the number of somites were counted, and after the initiation of 
heart function, heart rate was measured at the appropriate temperature and oxygen conditions. Temperature was controlled during the determination of heart rate using a temperature-controlled stage (20/20 Technology, Inc., Wilmington, NC) mounted on a microscope (Leica, DMIL inverted compound microscope) within the Bactrox hypoxic chamber. At the end of the experiment, individual embryos were blotted dry using a mesh screen over a stack of paper towels, weighed, and flash-frozen in $0.65 \mathrm{ml}$ microcentrifuge tube by submersion in liquid nitrogen.

\section{DNA quantification}

The amount of total DNA per embryo was determined using a Quant-iT dsDNA broad range assay kit (Invitrogen, Eugene, OR). Working reagent and standard curves were generated according to the manufacture's instructions using $200 \mu \mathrm{l}$ of working reagent and $10 \mu \mathrm{l}$ of each standard in a flat-bottom black 96-well plate (Costar). One $\mu \mathrm{l}$ of 1:9 diluted embryo homogenate and $9 \mu \mathrm{l}$ of water were added for each experimental sample. Total fluorescence was measured using an excitation of wavelength of $480 \mathrm{~nm}$ and an emission wavelength of $530 \mathrm{~nm}$ (Tecan Infinite M200 Pro microplate reader). 
The effects of hypoxia on the capacity for metabolic enzyme activity

Embryo homogenates were prepared by adding $10 \mathrm{mM}$ tris $(\mathrm{pH}=7.2)$ to a final dilution of $10 \mathrm{x}$ by mass $(1: 9$, mass $(\mathrm{g}) \times 9=$ volume in $\mathrm{ml}$ of Tris added). The tris buffer was added directly to the microcentrifuge tube containing the frozen embryo, and the embryo was homogenized in the tube using an acrylic pellet pestle (Thomas Scientific). The homogenate was used directly for determination of phosphoenolpyruvate carboxykinase (PEPCK) enzymatic capacity. A 20x (1:19) dilution of the homogenate was prepared by dilution with additional tris buffer (1:1 homogenate:tris buffer) for the determination of enzymatic activities for citrate synthase (CS) and lactate dehydrogenase (LDH). After use for the enzyme assays, all remaining homogenates were stored at $-20^{\circ} \mathrm{C}$ for later quantification of DNA. All enzyme assays were conducted at a temperature of $25^{\circ} \mathrm{C}$ in water-jacketed cell using a UV/VIS spectrophotometer (Shimadzu PharmaSpec 1700). Data were recorded using UVProbe software (Version 2.01, Shimadzu), and were exported into Prism software (Version 5.0, GraphPad Software) for determination of slopes and enzymatic activities.

\section{Citrate synthase}

Citrate synthase (CS) enzymatic activity was determined as described previously (Chennault and Podrabsky, 2010) on individual embryos. Each assay consisted for $1 \mathrm{ml}$ of $50 \mathrm{mM}$ imidazole buffer (pH $8 @ 25^{\circ} \mathrm{C}$ ), $1.5 \mathrm{mM} \mathrm{KCl}, 0.1 \mathrm{mM}$ 
DTNB, and $0.1 \mathrm{mM}$ acetyl-coenzyme A. Background activity was measured for 5 min after the addition of $10 \mu \mathrm{l}$ of 1:19 diluted embryo homogenate. The CS reaction was then initiated by the addition of $12.5 \mu \mathrm{l}$ of $0.7 \mathrm{mM}$ oxaloacetic acid. An increase in absorbance at $412 \mathrm{~nm}$ was monitored for $10 \mathrm{~min}$ and the last 30 sec used to calculate a slope for CS activity.

\section{Lactate dehydrogenase}

Lactate dehydrogenase (LDH) enzymatic activity was determined as described in previously (Chennault and Podrabsky, 2010) on individual embryos. Each assay consisted of $1 \mathrm{ml}$ of assay buffer containing $80 \mathrm{mM}$ imidazole $(\mathrm{pH}=$ $\left.7.2 @ 25^{\circ} \mathrm{C}\right), 100 \mathrm{mM} \mathrm{KCl}, 0.15 \mathrm{mM} \mathrm{NADH}$, and $4 \mathrm{mM}$ pyruvic acid prepared in reagent grade water. The reaction was initiated by the addition of $0.005 \mathrm{ml}$ of a 1:19 diluted homogenate. Disappearance of NADH was monitored at a wavelength of $340 \mathrm{~nm}$. Initial slopes were determined on $30 \mathrm{sec}$ of data starting at $10 \mathrm{sec}$ after addition of the embryo homogenate. Data are expressed in International Units (IU, $\mu \mathrm{mol}$ substrate $\mathrm{min}^{-1}$ ).

\section{Phosphoenolpyruvate carboxykinase}

Phosphoenolpyruvate carboxykinase (PEPCK) enzymatic activity was determined on individual embryos based on the methods outlined in (Lockwood and Somero, 2012). Each assay consisted of $1 \mathrm{ml}$ of assay buffer containing 100 
$\mathrm{mM}$ imidazole- $\mathrm{HCl}\left(\mathrm{pH}=6.9 @ 20^{\circ} \mathrm{C}\right), 1 \mathrm{mM} \mathrm{MnCl} 2,1 \mathrm{mM} \mathrm{MgCl} 2,20 \mathrm{mM}$ $\mathrm{NaHCO}_{3}, 1 \mathrm{mM}$ GDP, $0.15 \mathrm{mM} \mathrm{NADH}$, and $5 \mathrm{U} / \mathrm{ml} \mathrm{MDH}$ prepared in reagent grade water. Background activity was measured for $5 \mathrm{~min}$ after the addition of $0.01 \mathrm{ml}$ of 1:9 diluted embryo homogenate. The PEPCK reaction was then initiated by the addition of $0.04 \mathrm{ml}$ of $25 \mathrm{mM}$ PEP. Disappearance of NADH was monitored at a wavelength of $340 \mathrm{~nm}$ and the first $60 \mathrm{sec}$ of data starting $10 \mathrm{sec}$ after addition of the embryo homogenate was used to calculate a slope for PEPCK activity.

\section{Statistics}

Statistical analyses were performed using Prism 5.0 (Graphpad Software Inc., 1994-2010) and Microsoft Office Excel (2010). A two-way ANOVA was performed on the $25^{\circ} \mathrm{C}$ and $30^{\circ} \mathrm{C}$ data to test for differences in developmental progression and heart rate at the various levels of $\mathrm{PO}_{2}$. Bonferroni corrected post-hoc tests were then used to determine which $\mathrm{PO}_{2}$ treatments were significantly different at the two experimental temperatures.

To understand differences in DNA content and enzyme activity relative to $\mathrm{PO}_{2}$ first a one-way ANOVA was used. Student-Newman-Keuls multiple comparison post-hoc tests were used to test for the effects of $\mathrm{PO}_{2}$ within each experimental temperature. In addition, two-way ANOVA was used to compare the interaction between temperature and $\mathrm{PO}_{2}$. Bonferroni corrected post-hoc 
tests were used to determine at which levels of $\mathrm{PO}_{2}$ the means were significantly different between the two experimental temperatures. 


\section{Chapter 2}

\section{Results}

The effects of hypoxia on developmental progression

Development was delayed significantly at low partial pressures of oxygen at both incubation temperatures (Figures 1 and 2, Table 1; Two-way ANOVA, F = 392 and $\mathrm{p}<0.0001$ for $25^{\circ} \mathrm{C} \mathrm{PO}_{2}, \mathrm{~F}=359$ and $\mathrm{p}<0.0001$ for $30^{\circ} \mathrm{C} \mathrm{PO}_{2}, \mathrm{~F}=1044$ and $\mathrm{p}<0.0001$ for $30^{\circ} \mathrm{CPO}_{2}$ including $3.6 \mathrm{PO}_{2}, \mathrm{~F}=676$ and $\mathrm{p}<0.0001$ for $30^{\circ} \mathrm{C}^{\mathrm{PO}_{2}}$ including 2.2 $\mathrm{PO}_{2} ; \mathrm{F}=1859$ and $\mathrm{p}<0.0001$ for Wourms' stage). In the early developmental stages, $\mathrm{PO}_{2}$ did not have an effect on developmental progression at either temperature (Figures 1 and 2, Table 1). In fact, developmental progression was not significantly delayed by even the lowest level of hypoxia used in this study until after post-diapause II development at $25^{\circ} \mathrm{C}$, and at a similar stage of development at $30^{\circ} \mathrm{C}$ (Figures 1 and 2, Table 1; Bonferroni corrected t-tests, $\mathrm{p}<0.05)$. Incubation at $30^{\circ} \mathrm{C}$ accelerated the rate of development at all $\mathrm{PO}_{2}$ 's except at 3.6 and $2.2 \mathrm{kPa}$, where a significant retardation of development was observed and embryos were not able to complete development even after 104 days of incubation. Embryos incubated at $25^{\circ} \mathrm{C}$ and a $\mathrm{PO}_{2}$ of $21.2 \mathrm{kPa}$ reached completion of development (stage 43 , diapause III) at an average of 43 days whereas embryos raised at $2.2 \mathrm{PO}_{2}$ took an average of 85 days to reach the same benchmark. Embryos incubated at an increased 
temperature of $30^{\circ} \mathrm{C}$ and a $\mathrm{PO}_{2}$ of $21.2 \mathrm{kPa}$ took an average of 28 days to complete development compared to an average of 43 days for embryos exposed to a $\mathrm{PO}_{2}$ of $6.1 \mathrm{kPa}$. Greater differences in development occurred at more severe levels of hypoxia for both incubation temperatures. 


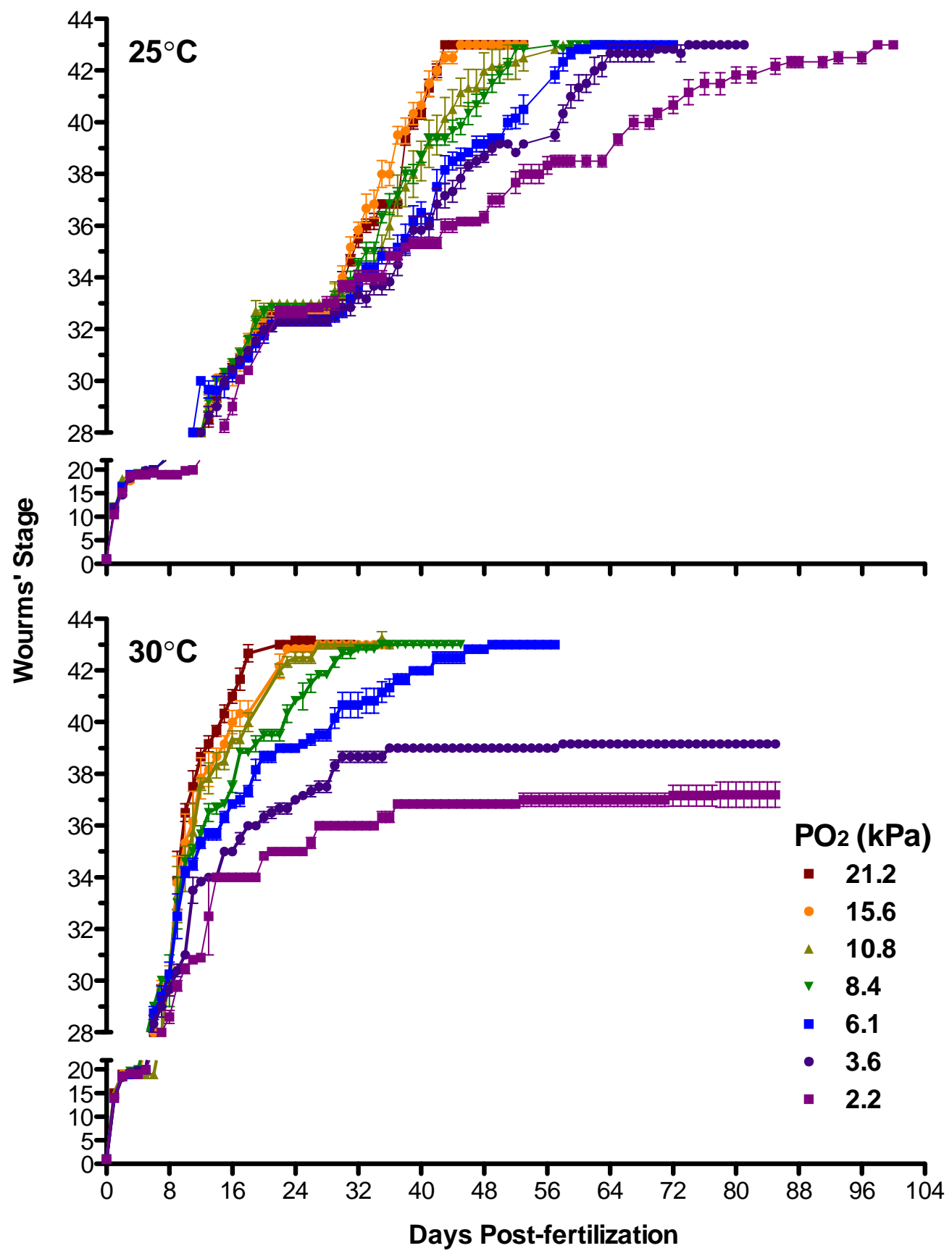

Figure 1. Developmental progression expressed as Wourms' stage as a function of developmental time in embryos incubated at 25 and $30^{\circ} \mathrm{C}$ over a range of oxygen partial pressures. Reduced $\mathrm{PO}_{2}$ caused a significant delay in embryo development at both incubation temperatures (see caption for Figure 2, and Table 1). Note that embryos exposed at $30^{\circ} \mathrm{C}$ to 3.6 and $2.2 \mathrm{PO}_{2}$ did not complete development by the end of the experiment. 


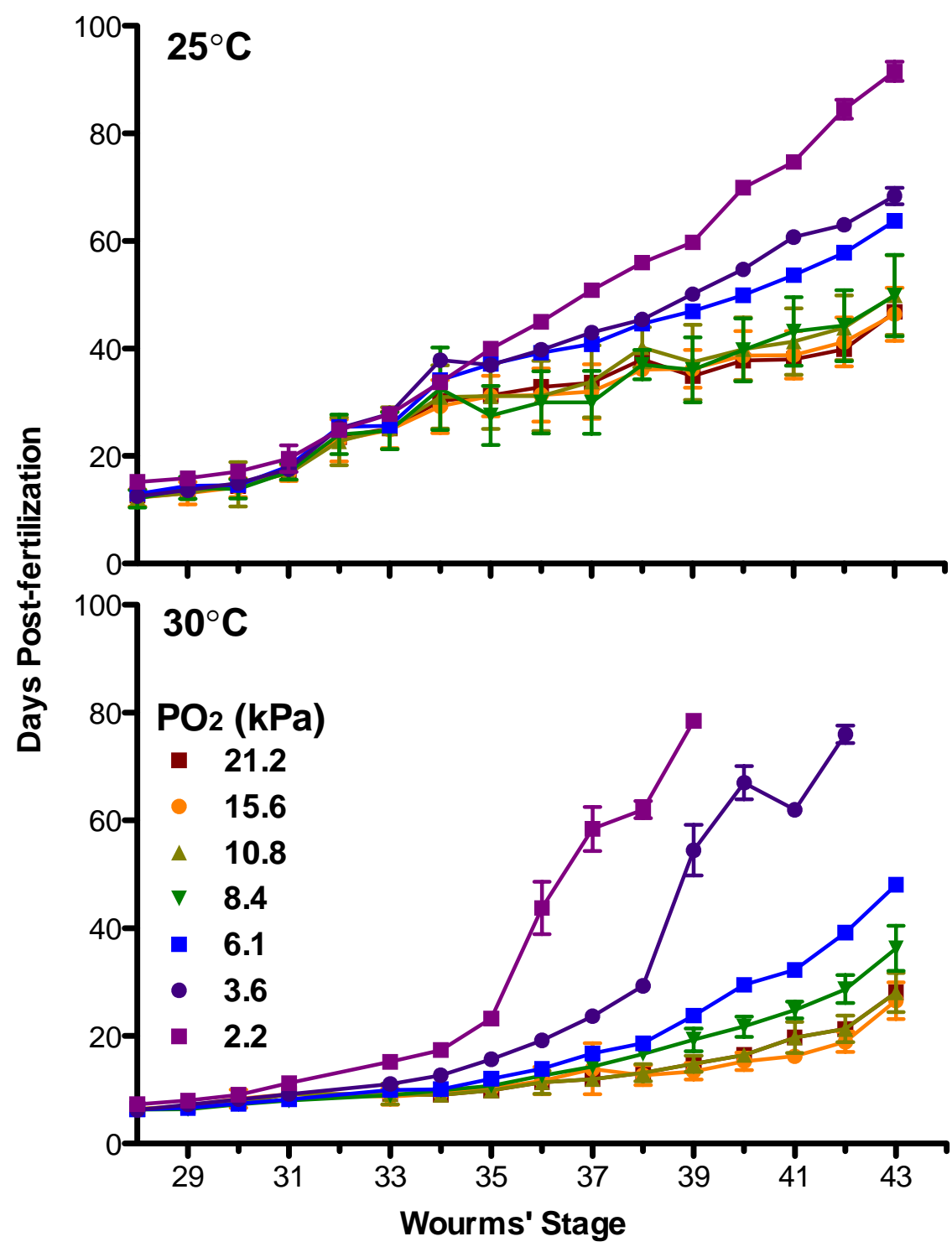

Figure 2. Average time in days to reach each developmental stage (Wourms' Stage) for embryos incubated at 25 and $30^{\circ} \mathrm{C}$ and a range of oxygen partial pressures. Development is delayed at low partial pressures of oxygen at both incubation temperatures (Two-way ANOVA, $\mathrm{F}=392$ and $\mathrm{p}<0.0001$ for $25^{\circ} \mathrm{CPO}_{2}, \mathrm{~F}=359$ and $\mathrm{p}<0.0001$ for $30^{\circ} \mathrm{CPO}_{2}, \mathrm{~F}=1044$ and $\mathrm{p}<0.0001$ for $30^{\circ} \mathrm{C}^{\mathrm{PO}_{2}}$ including 3.6, $\mathrm{F}=676$ and $\mathrm{p}<0.0001$ for $30^{\circ} \mathrm{C} \mathrm{PO}_{2}$ including $2.2 ; \mathrm{F}=1859$ and $\mathrm{p}<0.0001$ for $25^{\circ} \mathrm{C}$ Wourms' stage, $\mathrm{F}=1490$ and $\mathrm{p}<0.0001$ for $30^{\circ} \mathrm{C}$ Wourms' stage, $\mathrm{F}=1193$ and $\mathrm{p}<0.0001$ for $30^{\circ} \mathrm{C}$ Wourms' stage including $3.6, \mathrm{~F}=717$ and $\mathrm{p}<0.0001$ for $30^{\circ} \mathrm{C}$ Wourms' stage including 2.2). Early development (prior to stage 33) was not delayed even at the lowest levels of oxygen used in this study (see Figure 1 and Table 1). Note that the $\mathrm{x}$-axis starts at stage 28 (solid neural keel) and embryos incubated at $30^{\circ} \mathrm{C}$ the 3.6 and $2.2 \mathrm{PO}_{2}$ did not complete development by the end of the experiment. 
Effects of hypoxia on heart rate

Hypoxia caused a significant decrease in heart rate at both incubation temperatures (Figures 3 and 4, Table 2; Two-way ANOVA, $F=40$ and $p<0.0001$ for $25^{\circ} \mathrm{C} \mathrm{PO}_{2}, \mathrm{~F}=55$ and $\mathrm{p}<0.0001$ for $30^{\circ} \mathrm{CPO}_{2}, \mathrm{~F}=171$ and $\mathrm{p}<0.0001$ for $30^{\circ} \mathrm{C}$

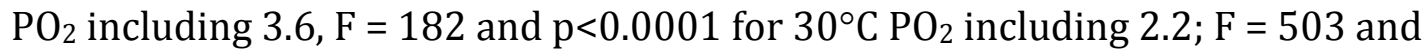
$\mathrm{p}<0.0001$ for $25^{\circ} \mathrm{C}$ Wourms' stage, $\mathrm{F}=73$ and $\mathrm{p}<0.0001$ for $30^{\circ} \mathrm{C}$ Wourms' stage, $\mathrm{F}=73$ and $\mathrm{p}<0.0001$ for $30^{\circ} \mathrm{C}$ Wourms' stage including $3.6, \mathrm{~F}=73$ and $\mathrm{p}<0.0001$ for $30^{\circ} \mathrm{C}$ Wourms' stage including 2.2). At $25^{\circ} \mathrm{C}$, heart rates where not affected during pre-diapause II development, but post-diapause II heart rates were reduced at lower partial pressures of oxygen when compared at the same developmental stages (Figure 4, Table 2). At $30^{\circ} \mathrm{C}$ the effect of hypoxia on heart rate was even more pronounced (Figure 4, Table 2). 


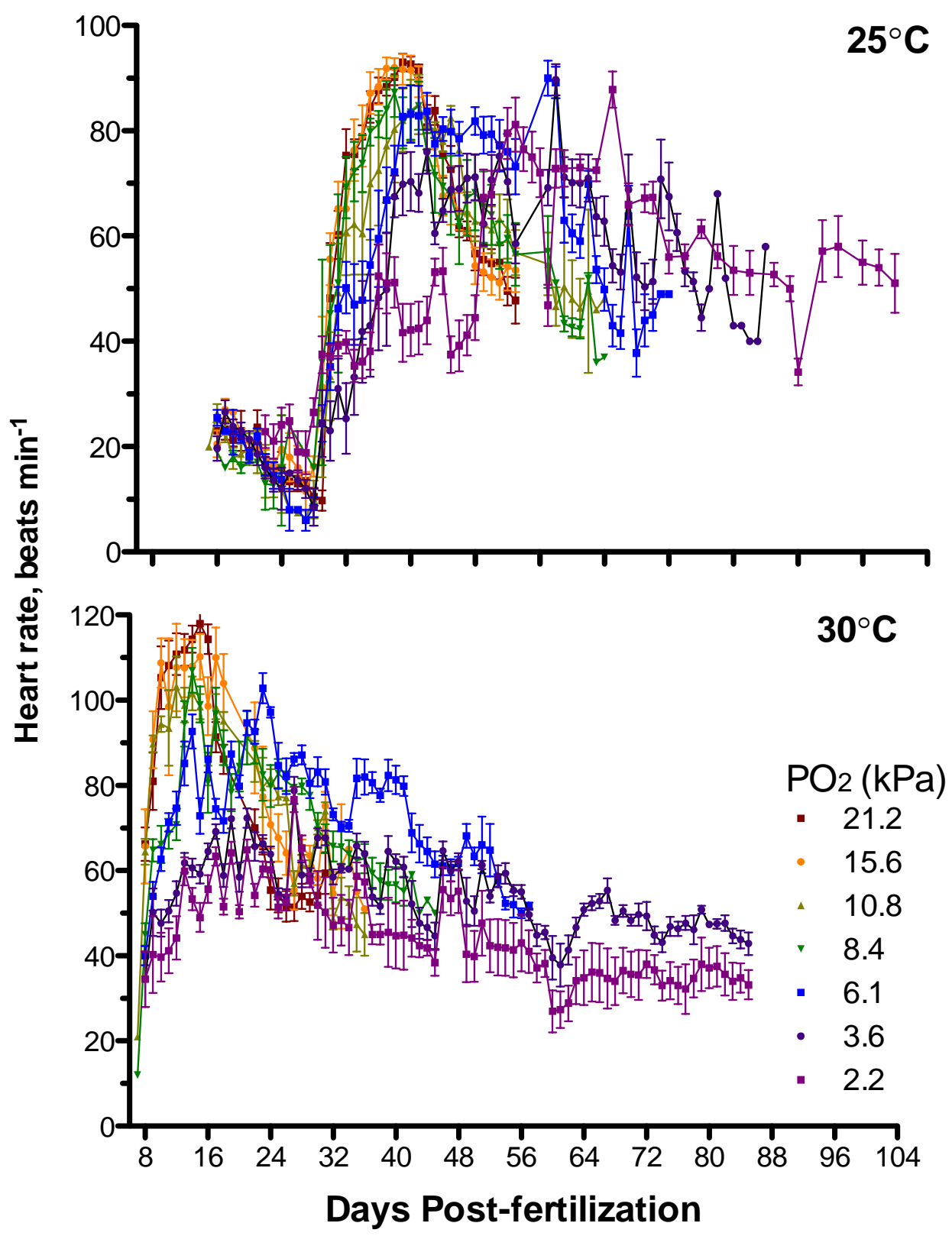

Figure 3. Heart rate (bpm) as a function of days post-fertilization. Embryos developing at low partial pressures of oxygen have reduced heart rates at both incubation temperatures (See Figure 4 , and Table 2). Note that embryos incubated at $30^{\circ} \mathrm{C}$ and a $\mathrm{PO}_{2}$ of 3.6 and $2.2 \mathrm{kPa}$ did not complete development by the end of the experiment. Symbols are means \pm sem. $(n=3-18)$. 


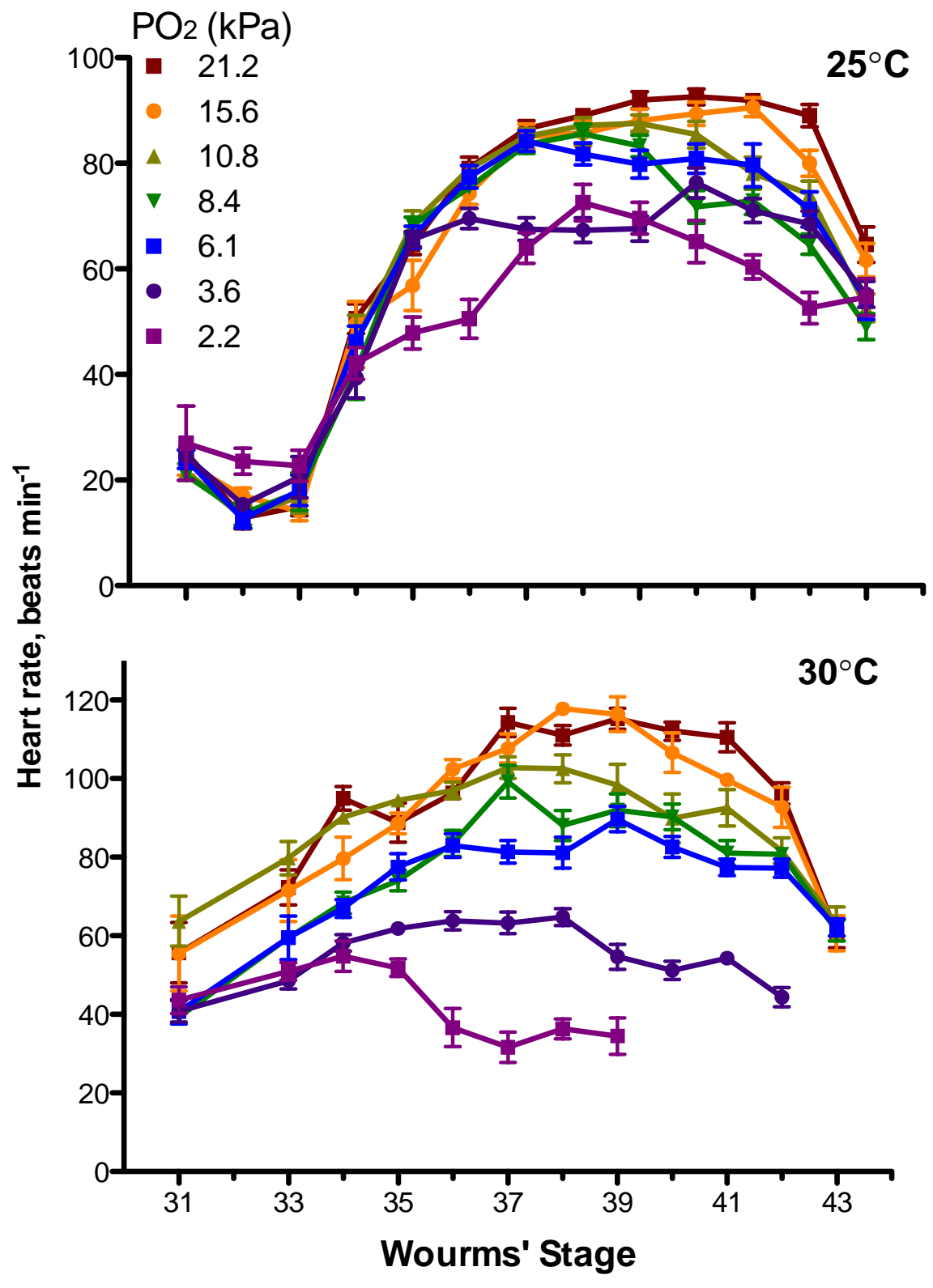

Figure 4. Heart rate (bpm) relative to developmental stage (Wourms' stage) in embryos developing at 25 and $30^{\circ} \mathrm{C}$ across a range of $\mathrm{PO}_{2}$. Heart rate is reduced in embryos developing at low partial pressures of oxygen at both incubation temperatures (Two-way ANOVA, $\mathrm{F}=40$ and $\mathrm{p}<0.0001$ for $25^{\circ} \mathrm{C} \mathrm{PO}, \mathrm{F}=55$ and $\mathrm{p}<0.0001$ for $30^{\circ} \mathrm{C} \mathrm{PO}, \mathrm{F}=171$ and $\mathrm{p}<0.0001$ for $30^{\circ} \mathrm{C}^{\mathrm{PO}_{2}}$ including 3.6, $\mathrm{F}=182$ and $\mathrm{p}<0.0001$ for $30^{\circ} \mathrm{C} \mathrm{PO}_{2}$ including $2.2 ; \mathrm{F}=503$ and $\mathrm{p}<0.0001$ for $25^{\circ} \mathrm{C}$ Wourms' stage, $\mathrm{F}=73$ and $\mathrm{p}<0.0001$ for $30^{\circ} \mathrm{C}$ Wourms' stage, $\mathrm{F}=73$ and $\mathrm{p}<0.0001$ for $30^{\circ} \mathrm{C}$ Wourms' stage including $3.6, \mathrm{~F}=73$ and $\mathrm{p}<0.0001$ for $30^{\circ} \mathrm{C}$ Wourms' stage including 2.2). Note that embryos incubated at $30^{\circ} \mathrm{C}$ and 3.6 and $2.2 \mathrm{kPa} \mathrm{PO}_{2}$ did not complete development by the end of the experiment. Symbols are means \pm sem. $(n=3-18)$. 
Table 1. Results of Two-way ANOVA with Bonferroni corrected post hoc tests to compare average time to reach each development stage in embryos incubated at $21.2 \mathrm{kPa} \mathrm{PO}_{2}$ to those incubated in reduced $\mathrm{pO}_{2}$ conditions.

\begin{tabular}{|c|c|c|c|c|c|c|c|}
\hline $\mathrm{T},{ }^{\circ} \mathrm{C}$ & $\mathbf{W S}^{\mathbf{a}}$ & $\begin{array}{l}\mathrm{PO}_{2}{ }^{\mathrm{b}} \\
15.6\end{array}$ & 10.8 & 8.4 & 6.1 & 3.6 & 2.2 \\
\hline \multirow[t]{18}{*}{25} & 17 & $n s^{c}$ & ns & ns & ns & $\mathrm{ns}$ & ns \\
\hline & 18 & ns & ns & ns & ns & ns & ns \\
\hline & 19 & ns & ns & ns & ns & ns & ns \\
\hline & 28 & ns & ns & ns & ns & ns & ns \\
\hline & 29 & ns & ns & ns & ns & ns & ns \\
\hline & 30 & ns & ns & ns & ns & ns & ns \\
\hline & 31 & ns & ns & ns & ns & ns & ns \\
\hline & 32 & ns & ns & ns & ns & ns & ns \\
\hline & 33 & ns & ns & ns & ns & ns & ns \\
\hline & 34 & ns & ns & ns & ns & 0.001 & ns \\
\hline & 35 & ns & ns & ns & 0.001 & 0.001 & 0.001 \\
\hline & 36 & ns & ns & ns & 0.001 & 0.001 & 0.001 \\
\hline & 37 & ns & ns & ns & 0.001 & 0.001 & 0.001 \\
\hline & 39 & ns & ns & ns & 0.001 & 0.001 & 0.001 \\
\hline & 40 & ns & ns & ns & 0.001 & 0.001 & 0.001 \\
\hline & 41 & ns & ns & 0.01 & 0.001 & 0.001 & 0.001 \\
\hline & 42 & ns & ns & 0.05 & 0.001 & 0.001 & 0.001 \\
\hline & 43 & ns & ns & ns & 0.001 & 0.001 & 0.001 \\
\hline \multirow[t]{18}{*}{30} & 14 & ns & ns & ns & ns & ns & ns \\
\hline & 19 & ns & ns & ns & ns & ns & ns \\
\hline & 20 & ns & ns & ns & ns & ns & ns \\
\hline & 28 & ns & ns & ns & ns & ns & ns \\
\hline & 29 & ns & ns & ns & ns & ns & ns \\
\hline & 30 & ns & ns & ns & ns & ns & ns \\
\hline & 31 & ns & ns & ns & ns & ns & ns \\
\hline & 33 & ns & ns & ns & ns & ns & 0.001 \\
\hline & 34 & ns & ns & ns & ns & 0.01 & 0.001 \\
\hline & 35 & ns & ns & ns & ns & 0.001 & 0.001 \\
\hline & 36 & ns & ns & ns & ns & 0.001 & 0.001 \\
\hline & 37 & ns & ns & ns & 0.001 & 0.001 & 0.001 \\
\hline & 38 & ns & ns & 0.01 & 0.001 & 0.001 & 0.001 \\
\hline & 39 & ns & ns & 0.001 & 0.001 & 0.001 & 0.001 \\
\hline & 40 & ns & ns & 0.001 & 0.001 & 0.001 & NA \\
\hline & 41 & ns & ns & 0.001 & 0.001 & 0.001 & NA \\
\hline & 42 & 0.01 & ns & 0.001 & 0.001 & 0.001 & NA \\
\hline & 43 & ns & ns & 0.001 & 0.001 & $N A^{d}$ & NA \\
\hline
\end{tabular}

a. WS = Wourms' Stage (Wourms, 1972)

b. $\mathrm{PO}_{2}$ in $\mathrm{kPa}$

c. ns = not significant, $p>0.05$, otherwise number represent the corrected p-value for the comparison.

d. NA = not applicable comparison because the embryos never reached this stage of development. 
Table 2. Results of Two-way ANOVA with Bonferroni corrected post hoc tests to compare heart rate in embryos incubated at $21.2 \mathrm{kPa} \mathrm{PO}_{2}$ to heart rates at equivalent developmental stages in embryos incubated in reduced $\mathrm{PO}_{2}$ conditions.

\begin{tabular}{|c|c|c|c|c|c|c|c|}
\hline $\mathrm{T},{ }^{\circ} \mathrm{C}$ & $\mathbf{W S}^{\mathbf{a}}$ & $\begin{array}{l}\mathrm{PO}_{2}{ }^{\mathrm{b}} \\
15.6\end{array}$ & 10.8 & 8.4 & 6.1 & 3.6 & 2.2 \\
\hline \multirow[t]{13}{*}{25} & 31 & $n s^{c}$ & ns & ns & ns & ns & ns \\
\hline & 32 & ns & ns & ns & ns & ns & ns \\
\hline & 33 & ns & ns & ns & ns & ns & ns \\
\hline & 34 & ns & ns & ns & ns & 0.05 & ns \\
\hline & 35 & ns & ns & ns & ns & ns & 0.001 \\
\hline & 36 & ns & ns & ns & ns & ns & 0.001 \\
\hline & 37 & ns & ns & ns & ns & 0.001 & 0.001 \\
\hline & 38 & ns & ns & ns & ns & ns & ns \\
\hline & 39 & ns & ns & ns & 0.01 & 0.001 & 0.001 \\
\hline & 40 & ns & ns & 0.001 & 0.05 & 0.001 & 0.001 \\
\hline & 41 & ns & 0.01 & 0.001 & 0.01 & 0.001 & 0.001 \\
\hline & 42 & ns & 0.01 & 0.001 & 0.001 & 0.001 & 0.001 \\
\hline & 43 & ns & 0.05 & 0.001 & 0.05 & ns & ns \\
\hline \multirow[t]{12}{*}{30} & 31 & ns & ns & ns & ns & ns & ns \\
\hline & 33 & ns & ns & ns & ns & 0.001 & 0.001 \\
\hline & 34 & ns & ns & 0.05 & 0.05 & 0.001 & 0.001 \\
\hline & 35 & ns & ns & ns & ns & 0.001 & 0.001 \\
\hline & 36 & ns & ns & ns & ns & 0.001 & 0.001 \\
\hline & 37 & ns & ns & 0.05 & 0.001 & 0.001 & 0.001 \\
\hline & 38 & ns & ns & 0.01 & 0.001 & 0.001 & 0.001 \\
\hline & 39 & ns & 0.01 & 0.001 & 0.001 & 0.001 & 0.001 \\
\hline & 40 & ns & 0.001 & 0.001 & 0.001 & 0.001 & NA \\
\hline & 41 & ns & 0.01 & 0.001 & 0.001 & 0.001 & NA \\
\hline & 42 & ns & 0.05 & 0.05 & 0.001 & 0.001 & NA \\
\hline & 43 & ns & ns & ns & ns & $N A^{d}$ & NA \\
\hline
\end{tabular}


The effect of hypoxia on total DNA content in Stage 43 embryos

There is a significant trend for decreasing total DNA content in stage 43 embryos that developed at low partial pressures of oxygen for both incubation temperatures (Two-way ANOVA, $\mathrm{F}=52$ and $\mathrm{p}=<0.0001$ for temperature; $\mathrm{F}=5.0$ and $\mathrm{p}=0.0002$ for $\mathrm{PO}_{2}$ ). Post hoc tests (Bonferroni corrected) did not show significant differences among mean DNA contents for embryos incubated at $25^{\circ} \mathrm{C}$ at various levels of oxygen. However, for embryos incubated at $30^{\circ} \mathrm{C}$ DNA content in the embryos that developed at a $\mathrm{PO}_{2}$ of $6.1 \mathrm{kPa}$ is significantly less compared to controls incubated at $21.2 \mathrm{kPa}$ (Figure 5; One-way ANOVA, SNK p = $<0.05)$.
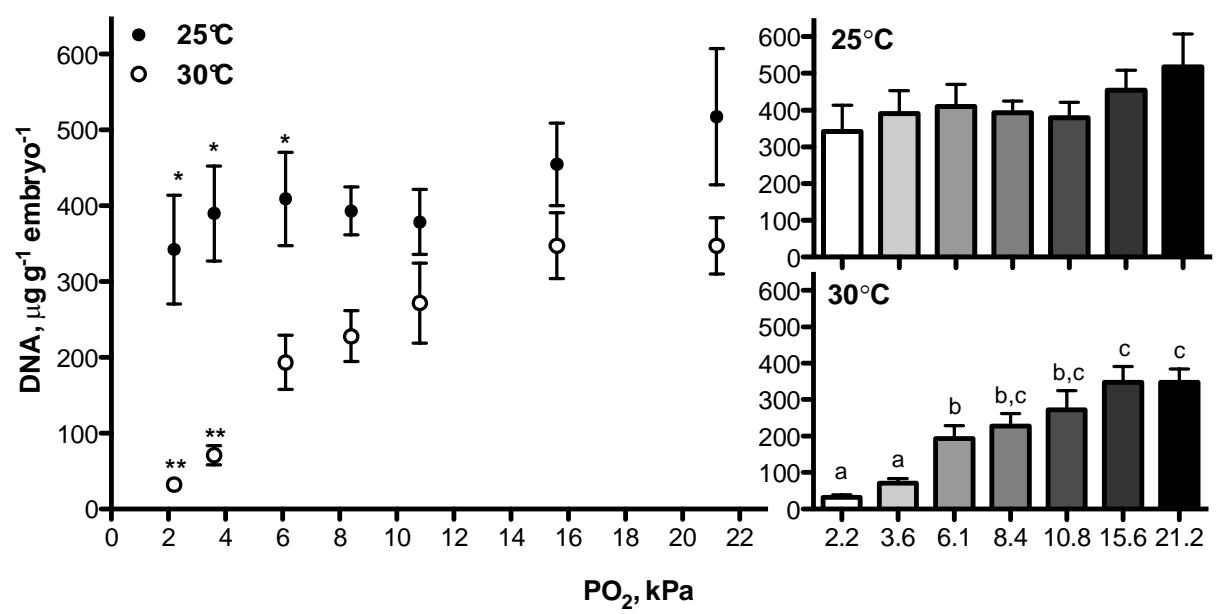

Figure 5. DNA quantity at the completion of development (Stage 43, diapause III) is reduced in embryos developing at low partial pressures of oxygen (Two-way ANOVA, $F=52$ and $p=<0.0001$ for temperature; $\mathrm{F}=5.0$ and $\mathrm{p}=0.0002$ for $\left.\mathrm{PO}_{2}\right)$. Symbols represent the mean \pm sem $(\mathrm{n}=4)$. Symbols with a single asterisk denote means that are statistically different between the two temperatures within an oxygen level (Bonferroni corrected $t$-tests, $p<0.05$ ). Symbols with double asterisks did not complete development by the end of the experiment. Bar graphs depict statistical differences within each temperature treatment as a function of $\mathrm{PO}_{2}$ (One-way ANOVA, SNK post hoc tests). Bars represent means \pm sem $(n=4)$. Bars with different letters are statistically different. 
The effects of hypoxia on metabolic enzyme activity in stage 43 embryos

Citrate synthase

When expressed per gram of tissue, stage 43 embryos that developed at low partial pressures of oxygen had reduced capacity for citrate synthase activity at both incubation temperatures (Figure 6; Two-way ANOVA, F = 8.1 and $\mathrm{p}=$ 0.0069 for temperature; $\mathrm{F}=41$ and $\mathrm{p}<0.0001$ for $\mathrm{PO}_{2}$ ). However, for embryos that were able to complete development, there are no differences in citrate synthase activity between the two incubation temperatures.

When expressed per gram of total DNA, stage 43 embryos developing at low partial pressures of oxygen had reduced citrate synthase activity (Figure 7; Two-way ANOVA, $\mathrm{F}=0.84$ and $\mathrm{p}=0.36$ for temperature; $\mathrm{F}=5.7$ and $\mathrm{p}=0.0003$ for $\mathrm{PO}_{2}$ ); however, post hoc tests were not able to detect significant differences in mean values for embryos that were able to complete development (Figure 7). 


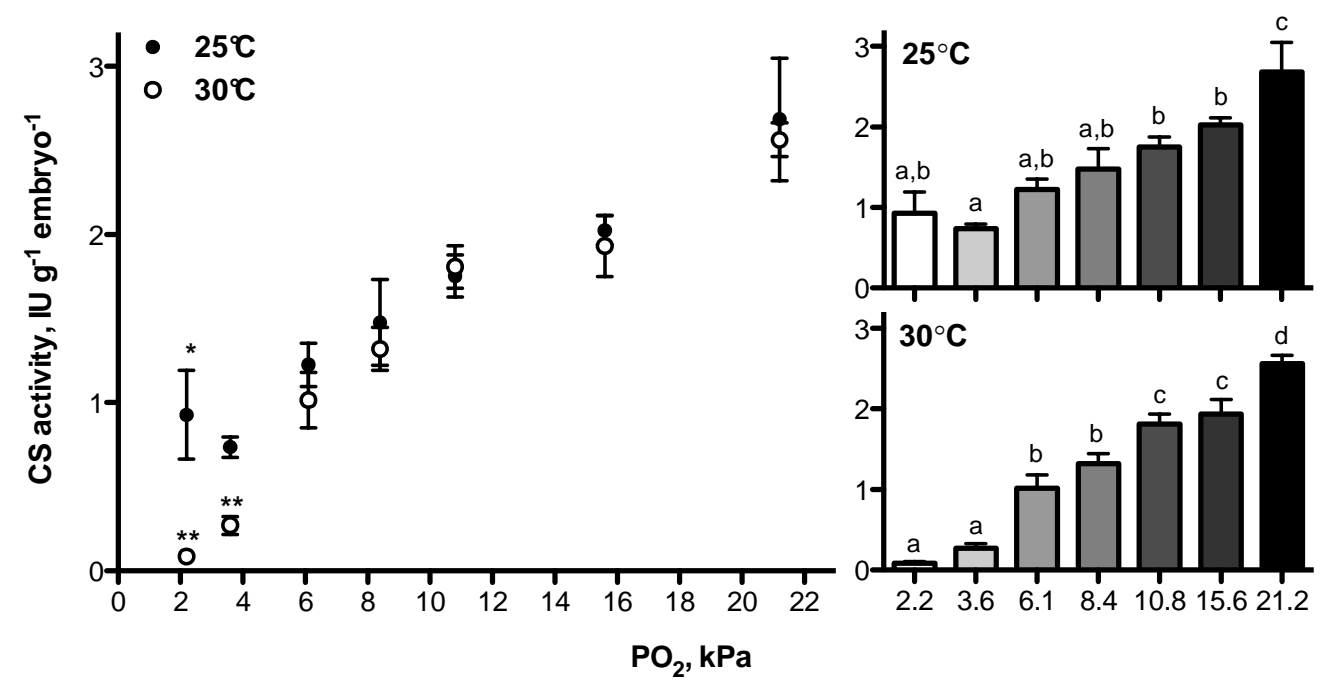

Figure 6. The enzymatic capacity for citrate synthase activity expressed per gram of tissue at the completion of development (Stage 43, diapause III) is reduced in embryos developing at low partial pressures of oxygen (Two-way ANOVA, $F=8.1$ and $p=0.0069$ for temperature; $F=41$ and $\mathrm{p}<0.0001$ for $\left.\mathrm{PO}_{2}\right)$. Symbols represent the mean $\pm \operatorname{sem}(\mathrm{n}=4)$. Symbols with a single asterisk denote means that are statistically different between the two temperatures within an oxygen level (Bonferroni corrected t-tests, $\mathrm{p}<0.05$ ). Symbols with double asterisks did not complete development by the end of the experiment. Bar graphs depict statistical differences within each temperature treatment as a function of $\mathrm{PO}_{2}$ (One-way ANOVA, SNK post hoc tests). Bars represent means \pm sem $(n=4)$. Bars with different letters are statistically different. 


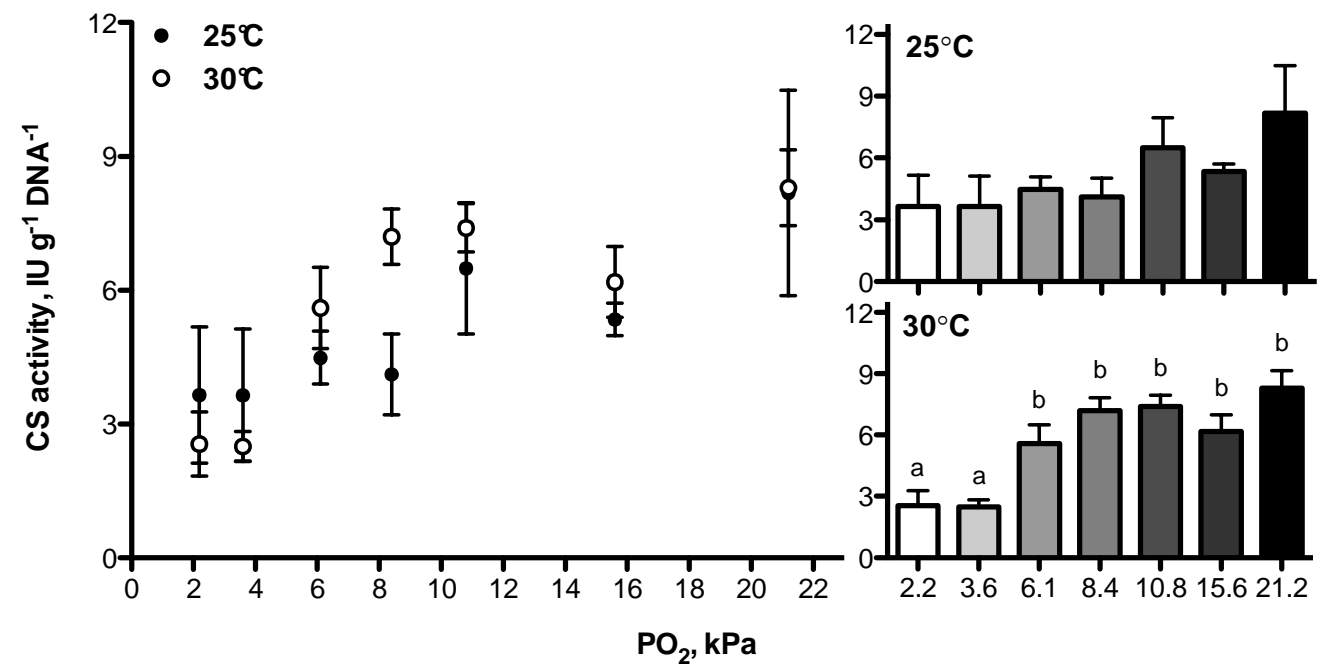

Figure 7. The enzymatic capacity for citrate synthase activity expressed per gram of DNA at the completion of development (Stage 43, diapause III) is reduced in embryos developing at low partial pressures of oxygen independent of incubation temperature (Two-way ANOVA, $\mathrm{F}=0.84$ and $\mathrm{p}=0.36$ for temperature; $\mathrm{F}=5.7$ and $\mathrm{p}=0.0003$ for $\mathrm{PO}_{2}$ ). However, this effect is likely due to the retardation of development observed in embryos incubated at $30^{\circ} \mathrm{C}$ at 2.2 and $3.6 \mathrm{kPa}$. Symbols represent the mean \pm sem $(n=4)$. Bar graphs depict statistical differences within each temperature treatment as a function of $\mathrm{PO}_{2}$ (One-way ANOVA, SNK post hoc tests). Bars represent means \pm sem $(n=4)$. Bars with different letters are statistically different. 
Lactate dehydrogenase

When expressed per gram of tissue, the capacity for lactate dehydrogenase activity is reduced in stage 43 embryos that developed at reduced partial pressures of oxygen (Figure 8; Two-way ANOVA, $F=23$ and $p=<0.0001$ for temperature; $\mathrm{F}=33$ and $\mathrm{p}<0.0001$ for $\mathrm{PO}_{2}$ ). Severe hypoxia and higher temperature had a greater effect of reducing the capacity for lactate dehydrogenase activity.

Stage 43 embryos that developed at low partial pressures of oxygen had similar capacities for lactate dehydrogenase activity expressed as a function of total DNA content, when compared to those exposed to atmospheric levels of oxygen at both incubation temperatures (Figure 9; Two-way ANOVA, $\mathrm{F}=0.007$ and $\mathrm{p}=0.9321$ for temperature; $\mathrm{F}=1.8$ and $\mathrm{p}=0.1162$ for $\mathrm{PO}_{2}$ ). Similarly to citrate synthase activity, the relationship between hypoxia and lactate dehydrogenase activity at $25^{\circ} \mathrm{C}$ shows no significant difference between partial pressures of oxygen, but at a higher temperature of $30^{\circ} \mathrm{C}$ severe hypoxia $(2.2$ and $3.6 \mathrm{kPa}$ ) caused a significant reduction in lactate dehydrogenase activity (Oneway ANOVA, $\mathrm{p}=<0.05$; SNK post hoc tests). 


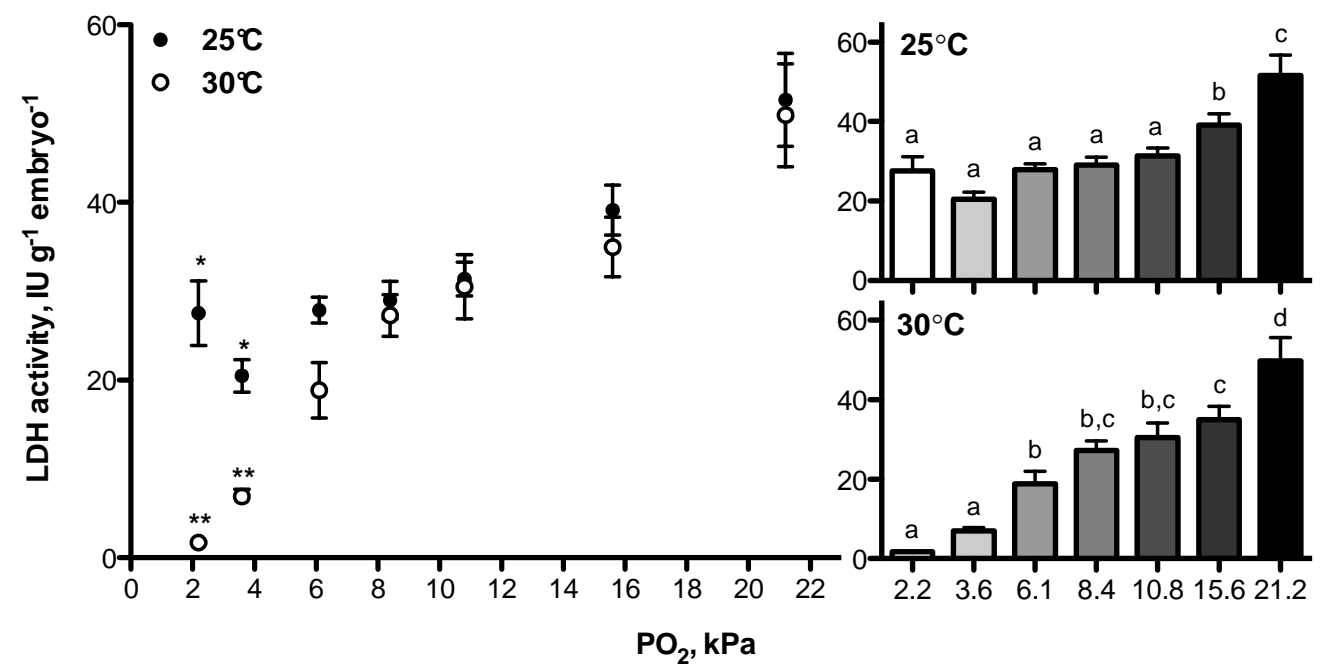

Figure 8. The enzymatic capacity for lactate dehydrogenase activity expressed per gram of tissue at the completion of development (Stage 43, diapause III) is reduced in embryos developing at low partial pressures of oxygen (Two-way ANOVA, $\mathrm{F}=23$ and $\mathrm{p}=<0.0001$ for temperature; $\mathrm{F}=$ 33 and $\mathrm{p}<0.0001$ for $\mathrm{PO}_{2}$ ). Symbols represent the mean \pm sem $(\mathrm{n}=4)$. Symbols with a single asterisk denote means that are statistically different between the two temperatures within an oxygen partial pressure (Bonferroni corrected t-tests, $\mathrm{p}<0.05$ ). Symbols with double asterisks did not complete development by the end of the experiment. Bar graphs depict statistical differences within each temperature treatment as a function of $\mathrm{PO}_{2}$ (One-way ANOVA, SNK post hoc tests). Bars represent means \pm sem $(n=4)$. Bars with different letters are statistically different. 


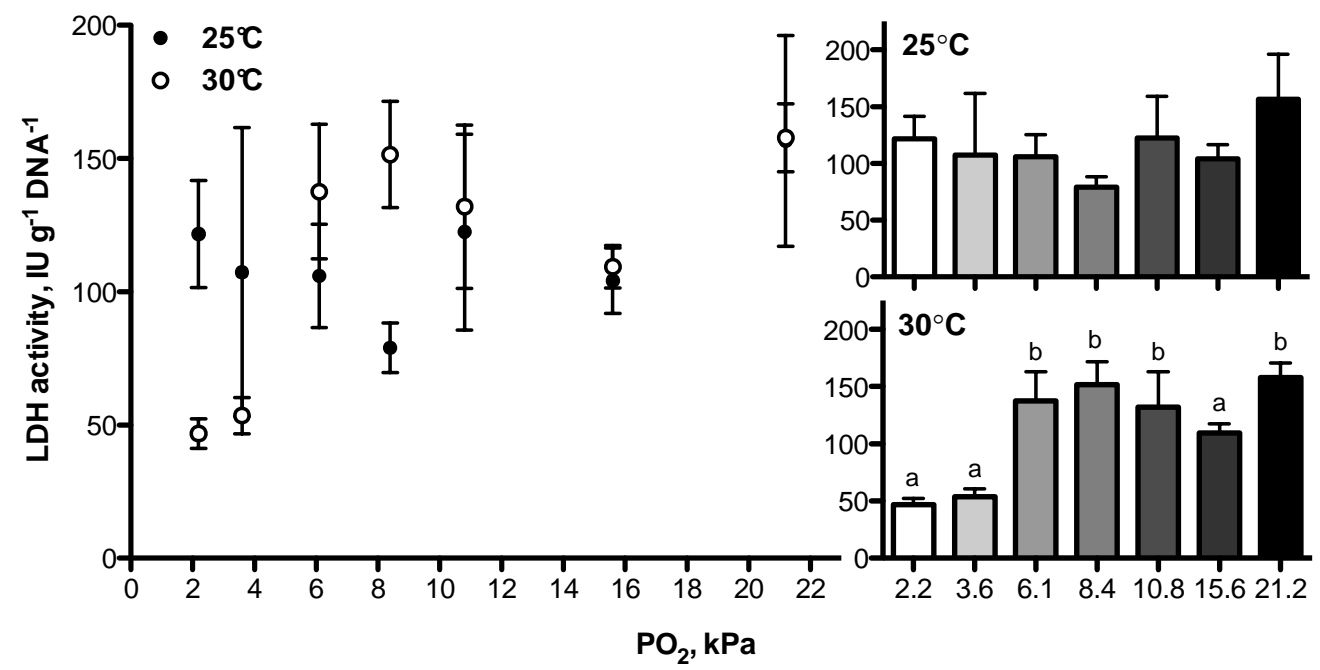

Figure 9. The enzymatic capacity for lactate dehydrogenase activity expressed per gram of DNA at the completion of development (Stage 43, diapause III) is not reduced in embryos developing at low partial pressures of oxygen at either incubation temperature (Two-way ANOVA, $\mathrm{F}=0.007$ and $\mathrm{p}=0.9321$ for temperature; $\mathrm{F}=1.8$ and $\mathrm{p}=0.1162$ for $\mathrm{PO}_{2}$ ). Symbols represent the mean \pm sem $(n=4)$. Bar graphs depict statistical differences within each temperature treatment as a function of $\mathrm{PO}_{2}$ (One-way ANOVA, SNK post hoc tests). Bars represent means \pm sem $(n=4)$. Bars with different letters are statistically different. 
Phosphoenolpyruvate carboxykinase

Stage 43 embryos that developed at low partial pressures of oxygen had reduced capacity for phosphoenolpyruvate carboxykinase (PEPCK) activity, but only at an incubation temperature of $30^{\circ} \mathrm{C}$ (Figure 10; Two-way ANOVA, F = 13 and $\mathrm{p}=0.0007$ for temperature; $\mathrm{F}=6.5$ and $\mathrm{p}<0.0001$ for $\mathrm{PO}_{2}$ ).

When expressed per gram of DNA, there were no differences in the capacity for PEPCK activity across the entire range of oxygen partial pressures and at both temperatures (Figure 11; Two-way ANOVA, $F=2.3$ and $p=0.1378$ for temperature; $\mathrm{F}=1.3$ and $\mathrm{p}=0.2966$ for $\mathrm{PO}_{2}$ ). 


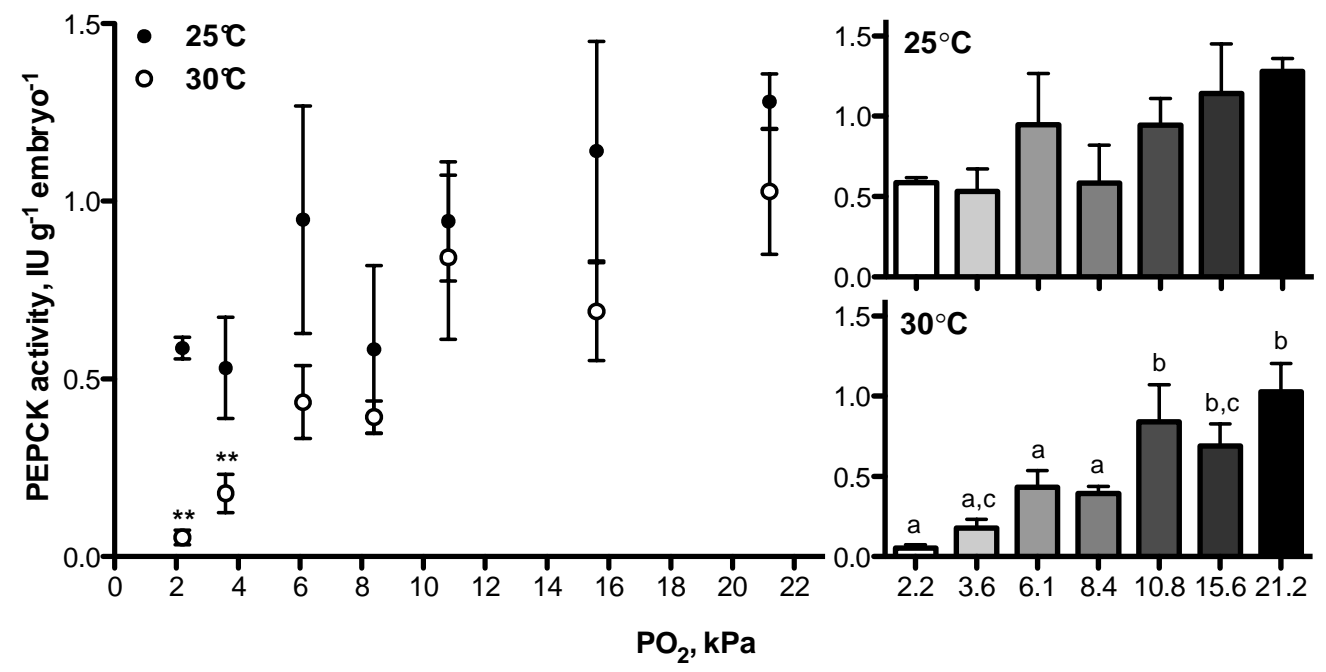

Figure 10. The enzymatic capacity for phosphoenolpyruvate carboxykinase activity expressed per gram of tissue at the completion of development (Stage 43, diapause III) is reduced in embryos that developed at low partial pressures of oxygen (Two-way ANOVA, $\mathrm{F}=13$ and $\mathrm{p}=$ 0.0007 for temperature; $\mathrm{F}=6.5$ and $\mathrm{p}<0.0001$ for $\left.\mathrm{PO}_{2}\right)$. Symbols represent the mean $\pm \operatorname{sem}(\mathrm{n}=4)$. Symbols with double asterisks did not complete development by the end of the experiment. Bar graphs depict statistical differences within each temperature treatment as a function of $\mathrm{PO}_{2}$ (Oneway ANOVA, SNK post hoc tests). Bars represent means \pm sem $(n=4)$. Bars with different letters are statistically different. 


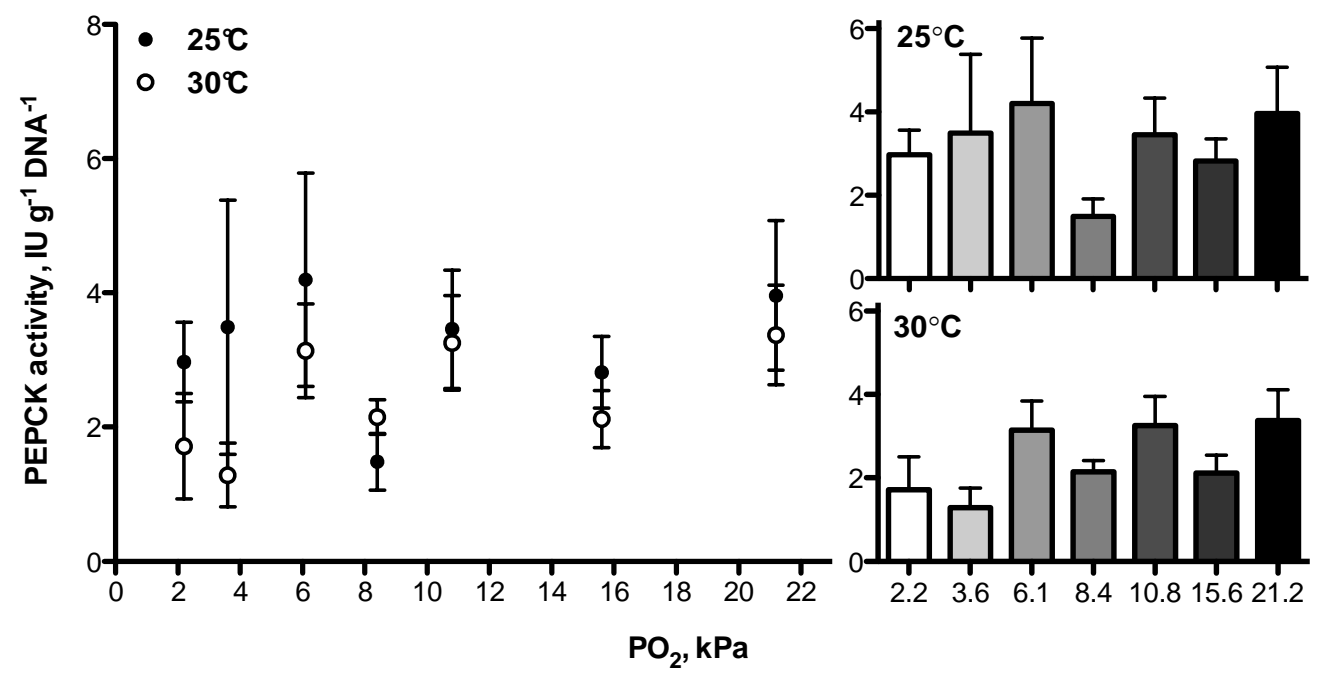

Figure 11. The enzymatic capacity for phosphoenolpyruvate carboxykinase activity expressed per gram of DNA at the completion of development (Stage 43, diapause III) is similar in embryos developing at low and high partial pressures of oxygen for both incubation temperatures (Twoway ANOVA, $F=2.3$ and $p=0.1378$ for temperature; $F=1.3$ and $p=0.2966$ for $\mathrm{PO}_{2}$ ). Symbols represent the mean \pm sem $(n=4)$. Bar graphs depict statistical differences within each temperature treatment as a function of $\mathrm{PO}_{2}$ (One-way ANOVA, SNK post hoc tests). Bars represent means $\pm \operatorname{sem}(n=4)$. 


\section{Discussion}

The effects of hypoxia and temperature on developmental progression

The effect of hypoxia on developmental progression in embryos of $A$.

limnaeus is different for early and late stage embryos. For early embryos, prior to stage 34 , there is no major effect of even severe hypoxia on the rate of development. In contrast, hypoxia clearly causes delayed development at both incubation temperatures in embryos beginning at stage 34 . The oxygendependent delay in development is exacerbated at the higher incubation temperature of $30^{\circ} \mathrm{C}$ to the extent that embryos exposed to severe hypoxia could not complete development even after 104 days. Data in the literature on other species of fish consistently show that low partial pressures of oxygen have a greater effect on later stages of development compared to early embryonic stages (Alderdice et al., 1958; Carlson and Siefert, 1974; Kaur and Toor, 1978; Spoor, 1977). Similar to the results presented here for A. limnaeus embryos, this pattern was also observed in whitefish (Coregonus albula), vendace (Coregonus lavaretus) (Czerkies et al., 2002) and largemouth bass (Micropterus salmoides) (Spoor, 1977). Hypoxia is often teratogenic in other fish species (Alderdice et al., 1958; Shang and $\mathrm{Wu}, 2004$ ) and in fact for most vertebrate species (Grabowski, 1961; Grabowski and Paar, 1958; Grabowski and Schroeder, 1968; Parer, 1998). However, in A. limnaeus embryos it takes a very severe dose of hypoxia and an 
increased temperature to inhibit development and still no major developmental anomalies were observed.

Studies show that most fish species cannot tolerate even brief exposures to hypoxia without suffering from developmental abnormalities, significant developmental delays, or even death. Embryos of the teleost fish Cyprinodon macularius were exposed to a reduced level of oxygen of $70 \%$ saturation $(\sim 15$ $\mathrm{kPa}$ ) at various temperature extremes and salinity. In this case, hypoxia slowed development and significantly affected tolerance to variations in temperature and salinity. As long as sufficient oxygen was available, these embryos could tolerate extreme temperatures (Kinne and Kinne, 1962). A study similar in design to the present investigation exposed Australian lungfish (Neoceratodus forsteri) embryos to hypoxia in order to investigate development and respiration (Mueller et al., 2011). Five different partial pressures of oxygen $(2,5,10,15$, and $20.9 \mathrm{kPa}$ ) were used at a constant temperature of $20^{\circ} \mathrm{C}$. Similar to the results presented here for $A$. limnaeus, the $N$. forsteri embryos exhibited delayed development at oxygen partial pressures of $10 \mathrm{kPa}$ and below. In contrast, the $N$. forsteri embryos raised under severe hypoxia of $2 \mathrm{kPa}$ did not survive whereas $A$. limnaeus embryos were able to complete development at $25^{\circ} \mathrm{C}$ and survived for over 100 days at $30^{\circ} \mathrm{C}$ although they were not able to complete development. Interestingly, embryos of $N$. forsteri hatched early when they developed under 
hypoxia (Mueller et al., 2011) while embryos of $A$. limnaeus took longer to develop and did not hatch earlier, but rather entered diapause III.

Embryos of other vertebrate classes also exhibit a general intolerance to hypoxia. Delayed development and early hatching was observed in frog embryos of the species Pseudophryne bibroni at low partial pressures of oxygen (Bradford and Seymour, 1988). Short bouts of hypoxia ( $6 \mathrm{~h}$ at $\sim 10 \mathrm{kPa}$ ) was enough to impair early stage development and decrease survival rates in chicken embryos (Altimiras and Phu, 2000). Another study using chicken embryos concluded that hypoxia had no impact on embryos raised at $21 \mathrm{kPa}$ and $15 \mathrm{kPa}$, but delayed development and malformations began to occur at hypoxia below $15 \mathrm{kPa}$ and became more severe with lower partial pressures (Grabowski, 1961).

The results of the study presented here are consistent with the literature on other species of fish and support the major hypothesis that embryos incubated at lower oxygen levels would develop more slowly than those incubated at higher oxygen levels. However, we did not observe major developmental abnormalities as was expected based on the data available from the literature for other fish species. The general increase in the rate of development and heart rate associated with incubation at $30^{\circ} \mathrm{C}$ compared to those at $25^{\circ} \mathrm{C}$ is also consistent with previous investigations and would be predicted based on basic principles of physiology. The reversal of this pattern under severe hypoxia is likely a consequence of a large imbalance between the 
metabolic demands of the embryos at the higher temperature and a limited ability to support the metabolic needs of the embryo through aerobic metabolism. Thus, late development in this species is dependent on aerobic metabolic pathways, and slight increases in temperature may have severe consequences for continued development. An alternate explanation of these results could be centered around specific metabolic adaptations associated with entrance into diapause at $25^{\circ} \mathrm{C}$ that support development under lower oxygen conditions. However, the metabolic pathways that might be altered are currently unknown, and obviously do not rely on increases in enzymatic capacity for LDH, CS, or PEPCK (see below).

The effect of hypoxia on heart rate during embryological development

In the present study hypoxia caused a decrease in the stage-specific heart rate of embryos at both incubation temperatures, with more severe hypoxia leading to larger decreases in heart rate. In addition, heart rate reduction is greater in later developmental stages, especially under severe hypoxia. The only exception to this trend is that heart rate in pre-diapause II development at $25^{\circ} \mathrm{C}$ appears to be unaffected by oxygen partial pressure. Stage 34 appears to be a critical time when development becomes sensitive to lack of oxygen in this species, at both 25 and $30^{\circ} \mathrm{C}$. This is important, because this stage of development is just post-diapause II when embryos are incubated at $25^{\circ} \mathrm{C}$. It is 
interesting that this pattern is also observed in embryos that do not enter diapause II due to incubation at $30^{\circ} \mathrm{C}$. It appears that the physiology of early development, from fertilization up to stage 34 may proceed almost independent of oxygen availability in A. limnaeus. This may be due to the lower metabolic demands in these early embryos, and/or a heavier reliance on anaerobic metabolic pathways to support development.

Other fish species show similar trends in heart rate under hypoxia. The zebrafish species, Danio rerio, show an age-specific decline in heart rate under dissolved oxygen concentration of $2.1 \mathrm{kPa}$ with hypoxia introduced at the 8 cell stage (Bagatto, 2005). Hypoxia also delayed initial cardiovascular development (Bagatto, 2005). Another study on zebrafish showed that acute hypoxia had no significant effect on heart rate of developing embryos across a range of temperatures (Barrionuevo and Burggren, 1999). A significant effect of hypoxia on heart rate was not illustrated until the embryos had hatched and reached juvenile stage (Barrionuevo and Burggren, 1999).

The cardiovascular system of fish embryos appears to be rather insensitive to the effects of hypoxia during development, exhibiting either no effects or simply a reduction in heart rate. In contrast, other vertebrate species suffer greater consequences under these conditions. Chick embryos raised under $5.1 \mathrm{kPa}$ exhibit a range of heart defects such as an increased number of ventricles, septum defects, hemorrhaging, necrosis, and vessel misplacement (Jaffee, 1974), 
while those raised under $6.1 \mathrm{kPa}$ had an increase in heart size and blood vessel size (Grabowski and Schroeder, 1968).

Heart rate declined under hypoxic conditions in embryos of $A$. limnaeus, with more severe hypoxia leading to greater reductions in heart rate. However, no obvious developmental defects were observed, and in all cases circulation was not altered or disrupted in any major way. Thus, embryos of $A$. limnaeus appear to be able to support normal cardiovascular development across a range of oxygen partial pressures.

The effect of hypoxia on total DNA content of stage 43 embryos

In the A. limnaeus embryos studied here, hypoxia caused a reduction in the total embryonic DNA content at both incubation temperatures, although post-hoc tests were not able to distinguish which means in the $25^{\circ} \mathrm{C}$ treatments were different. Because DNA was quantified on embryos of the same developmental stage (stage 43 except for $30^{\circ} \mathrm{C} 3.6$ and $2.2 \mathrm{kPa}$ ), it was unexpected that DNA quantities would differ. There are three possible ways to explain this pattern. First, embryos raised under hypoxia may hatch with fewer cells. Second, because many vertebrate embryos are thought to contain large amounts of mitochondrial DNA (Dawid, 1965, 1966), it is possible that hypoxia causes a reduction in mitochondrial volume or at least mitochondrial DNA content. This hypothesis is consistent with the lower levels of CS activity (a mitochondrial enzyme) in 
hypoxia treated embryos. Third, if the yolk DNA is indeed "cytoplasmic DNA" as described by (Baltus et al., 1968), then differential degradation or utilization of this yolk DNA could explain the patterns observed. While unfertilized embryos of A. limnaeus have a significant amount of total DNA (Podrabsky and Hand, 1999), much greater than can be accounted for by the nuclear genome, the nature of the DNA has not been explored. The true nature and significance of this decrease in embryonic DNA content will have to await more detailed studies on the nature of the yolk DNA in this species, and the changes in the various "types" of DNA during development at various levels of hypoxia.

The effects of hypoxia on metabolic enzyme activity

Hypoxia has an effect on most vertebrate physiological systems. In adults and juveniles, hypoxia typically induces biochemical changes that support anaerobic metabolic pathways, sometimes at the expense of aerobic capacity (Papandreou et al., 2006). For example, juveniles of the common estuarine fish Leiostomus xanthurus show a significant increase in LDH activity and no significant change in citrate synthase activity in gill, liver, and muscle tissue when exposed to $10 \%$ oxygen saturation $(\sim 2.1 \mathrm{kPa})$ for only 12 hours (Cooper et al., 2002). In contrast, evidence from the work presented here for embryos of $A$. limnaeus and those from the literature for other species such as Altantic salmon (Matschak et al., 1998) suggest not only a lack of compensatory acclimation 
capacity in fish embryos, but rather a decrease in capacity for both aerobic and anaerobic pathways. It is plausible that reduced enzymatic capacities in embryos are explained by developmental constraints on plasticity in gene expression. Alternatively, it could be an adaptive mechanism to match rates of yolk consumption with available external resources such as oxygen. This could (in general) lead to more efficient usage of the finite yolk resources available for development. However, this also suggests that development can be supported across a wide range of metabolic and developmental rates, and there must presumably be mechanisms that maintain appropriate developmental sequences across organ systems such that the ontogeny of development is not greatly perturbed. In adults, there are many tissue-specific responses to hypoxia, but perhaps the need to maintain developmental sequences within a rather narrow range of values, has selected for a single response of all organ systems to a reduction in oxygen availability in embryos.

At the heart of the adult vertebrate response to hypoxia is a signaling pathway that depends on the oxygen-dependent activity of a transcription factor known as hypoxia-inducible factor-1, or HIF-1 (Papandreou et al., 2006). Activation of this transcription factor by reduced levels of oxygen typically leads to upregulation of the expression of genes involved in anaerobic energy production including most glycolytic enzymes and LDH and PEPCK, and often an active down-reguation of aerobic mitochondrial metabolism (Papandreou et al., 
2006). The uncanny ability of $A$. limnaeus embryos to survive for extended periods in severe hypoxia in the absence of an increase in LDH or PEPCK activity suggests either a lack of a canonical HIF-1 response or a dramatically altered response that does not result in a functional increase in these enzymes as is observed in other species. The activity of HIF-1 is currently not known in embryos of $A$. limnaeus, and future studies should focus on the possible role, (or lack thereof) for this highly conserved transcription factor in mediating survival of hypoxia in this species. 


\section{Chapter 3}

\section{Summary}

Hypoxia caused a significant decline in developmental rate in A. limnaeus embryos consistent with other fish species, but in contrast to many other species even under chronic and severe hypoxia no developmental abnormalities were observed. Increased incubation temperature caused an acceleration of developmental rate similar to that observed in other species of fish but without the early hatching observed in other species. Heart rate was decreased by hypoxia and severe hypoxia caused a stage-specific decline in heart rate. More advanced embryos experienced a greater decline in heart rate compared to controls for both incubation temperatures. Development in hypoxia resulted in embryos with less total DNA compared to those developing under control conditions. Embryos of A. limnaeus respond to environmental hypoxia by decreasing the capacity for enzymatic activity in metabolic pathways for aerobic and anaerobic metabolism.

\section{Future Investigations}

The data presented in this thesis pose many additional questions that deserve future attention. For example, based on rates of development, heart rate, and reduced capacity for enzymatic activity I would predict that embryos 
developing under hypoxia would have a decreased metabolic rate compared to those developing under normoxic conditions. Furthermore, it would be interesting to find out if the embryos that stalled development at $30^{\circ} \mathrm{C}$ (3.6 and $2.2 \mathrm{kPa}$ treatments) would recover if returned to normoxia. It is possible that this stall in development is equivalent to anoxia-induced quiescence because the oxygen level is functionally too low to support any form of aerobic metabolism. Another area that is ripe for investigation is the nature and distribution of DNA within the embryo and how these various compartments respond to development under hypoxia.

\section{Significance}

Most vertebrate species require oxygen to develop functionally and completely; therefore, the ability of $A$. limnaeus embryos to withstand periods of hypoxia and anoxia is of interest. The limited ability of vertebrates in general, and especially mammals, to sustain anaerobic metabolic pathways leads to many diseases and pathologies in humans, such as those associated with heart attack and stroke. By understanding how this exceptional organism is able to survive prolonged bouts of hypoxia and anoxia, perhaps we can identify ways to improve survival and prevent tissue damage associated with stroke or heart attacks. In addition, understanding the long-lasting effects of hypoxic exposures on fish 
during development may help us to better understand the long-term effects of hypoxic "dead zones" on coastal ecosystems. 


\section{References}

Alderdice DF, Wickett WP, Brett JR (1958) Some effects of temporary exposure to low dissolved oxygen levels on Pacific Salmon eggs. J Fish Res Board Can 15:229249

Altimiras J, Phu L (2000) Lack of physiological plasticity in the early chicken embryo exposed to acute hypoxia. J Exp Zool 286:450-456

Bagatto B (2005) Ontogeny of cardiovascular control in zebrafish (Danio rerio): Effects of developmental environment. Comp Biochem Physiol A 141:391-400

Baltus E, Hanocq-Quertier J, Brachet J (1968) Isolation of deoxyribonucleic acid from the yolk platelets of Xenopus laevis oocyte. Proc Natl Acad Sci USA 61:469476

Barrionuevo WR, Burggren WW (1999) $\mathrm{O}_{2}$ consumption and heart rate in developing zebrafish (Danio rerio): influence of temperature and ambient $\mathrm{O}_{2}$. Am J Physiol 276:R505-R513

Bradford DF, Seymour RS (1988) Influence of environmental $\mathrm{PO}_{2}$ on embryonic oxygen consumption, rate of development, and hatching in the frog Pseudophryne bibroni. Physiol Zool 61:475-482

Brahimi-Horn MC, Pouyssegur J (2007) Oxygen, a source of life and stress. FEBS Letters 581:3582-3591

Carlson AR, Siefert RE (1974) Effects of reduced oxygen on the embryos and larvae of Lake Trout (Salvelinus namaycush) and Largemouth Bass (Micropterus salmoides). J Fish Res Board Can 31:1393-1396

Chennault T, Podrabsky JE (2010) Aerobic and anaerobic capacities differ in embryos of the annual killifish Austrofundulus limnaeus that develop on alternate developmental trajectories. J Exp Zool A 313A:587-596

Cooper RU, Clough LM, Farwell MA, West TL (2002) Hypoxia-induced metabolic and antioxidant enzymatic activities in the estuarine fish Leiostomus xanthurus. J Exp Mar Biol Ecol 279:1-20

Czerkies P, Kordalski K, Golas T, Krysinski D, Luczynski M (2002) Oxygen requirements of whitefish and vendace (Coregoninae) embryos at final stages of their development. Aquaculture 211:375-385

Dawid IB (1965) Deoxyribonucleic acid in amphibian eggs. J Mol Biol 12:581-599 Dawid IB (1966) Evidence for the mitochondrial origin of frog egg cytoplasmic DNA. Proc Natl Acad Sci USA 56:269-276 
Diaz RJ, Rosenberg R (2008) Spreading dead zones and consequences for marine ecosystems. Science 321:926-929

DiMichele L, Powers DA (1984) The relationship between oxygen consumption rate and hatching in Fundulus heteroclitus. Physiol Zool 57:46-51

DiMichele L, Taylor MH (1980) The environmental control of hatching in Fundulus heteroclitus. J Exp Zool 214:181-187

DiMichele L, Taylor MH (1981) The mechanism of hatching in Fundulus heteroclitus: development and physiology. J Exp Zool 217:73-79

Felderhoff-Mueser U, Bittigau P, Sifringer M, Jarosz B, Korobowicz E, Mahler L, Piening T, Moysich A, Grune T, Thor F, Heumann R, B, hrer C, Ikonomidou C (2004) Oxygen causes cell death in the developing brain. Neurobiology of Disease $17: 273-282$

Finn RN, Widdows J, Fyhn HJ (1995) Calorespirometry of developing embryos and yolk-sac larvae of turbot (Scophthalmus maximus). Mar Biol 122:157-163

Grabowski CT (1961) A quantitative study of the lethal and teratogenic effects of hypoxia on the three-day chick embryo. Am J Anat 109:25-35

Grabowski CT, Paar JA (1958) The teratogenic effects of graded doses of hypoxia on the chick embryo. Am J Anat 103:313-347

Grabowski CT, Schroeder RE (1968) A time-lapse photographic study of chick embryos exposed to teratogenic doses of hypoxia. J Embryol Exp Morph 19:347362

Hrbek T, Taphorn DC, Thomerson JE (2005) Molecular phylogeny of Austrofundulus Myers (Cyprinodontiformes: Rivulidae), with revision of the genus and the description of four new species. Zootaxa 825:1-39

Jaffee OC (1974) The effects of moderate hypoxia and moderate hypoxia plus hypercapnea on cardiac development in chick embryos. Teratology 10:275-282

Kaur K, Toor HS (1978) Effect of dissolved oxygen on the survival and hatching of eggs of Scale Carp. Prog Fish-Cult 40:35-37

Kinne 0, Kinne EM (1962) Rates of development in embryos of a cyprinodont fish exposed to different temperature-salinity-oxygen combinations. Can J Zool 40:231-253

Lockwood BL, Somero GN (2012) Functional Determinants of Temperature Adaptation in Enzymes of Cold- versus Warm-Adapted Mussels (Genus Mytilus). Mol Biol Evol 29:3061-3070

Lutz PL (1992) Mechanisms for Anoxic Survival in the Vertebrate Brain. Ann Rev Physiol 54:601-618 
Lutz PL, Nilsson GE (1997) Contrasting strategies for anoxic brain survival glycolysis up or down. J Exp Biol 200:411-419

Lutz PL, Nilsson GE, Perez-Pinzon MA (1996) Anoxia tolerant animals from a neurobiological perspective. Comp Biochem Physiol 113B:3-13

Machado BE, Podrabsky JE (2007) Salinity tolerance in diapausing embryos of the annual killifish Austrofundulus limnaeus is supported by exceptionally low water and ion permeability. J Comp Physiol B 177:809-820

Matschak TW, Tyler DD, Stickland NC (1998) Metabolic enzyme activities in Atlantic salmon (Salmo salar L.) embryos respond more to chronic changes in oxygen availability than to environmental temperature. Fish Physiol Biochem 18:115-123

Mueller C, Joss J, Seymour RS (2011) Effects of environmental oxygen on development and respiration of Australian lungfish (Neoceratodus forsteri) embryos. J Comp Physiol B 181:941-952

Myers GS (1952) Annual fishes. Aqua J 23:125-141

Nilsson GE, Lutz PL (2004) Anoxia Tolerant Brains. J Cereb Blood Flow Metab 24:475-486

Papandreou I, Cairns RA, Fontana L, Lim AL, Denko NC (2006) HIF-1 mediates adaptation to hypoxia by actively downregulating mitochondrial oxygen consumption. Cell Met 3:187-197

Parer JT (1998) Effects of Fetal Asphyxia on Brain Cell Structure and Function: Limits of Tolerance. Comp Biochem Physiol A 119:711-716

Podrabsky JE (1999) Husbandry of the annual killifish Austrofundulus limnaeus with special emphasis on the collection and rearing of embryos. Env Biol Fish 54:421-431

Podrabsky JE, Carpenter JF, Hand SC (2001) Survival of water stress in annual fish embryos: dehydration avoidance and egg envelope amyloid fibers. Am J Physiol 280:R123-R131

Podrabsky JE, Garrett IDF, Kohl ZF (2010) Alternative developmental pathways associated with diapause regulated by temperature and maternal influences in embryos of the annual killifish Austrofundulus limnaeus. J Exp Biol 213:32803288

Podrabsky JE, Hand SC (1999) The bioenergetics of embryonic diapause in an annual killifish, Austrofundulus limnaeus. J Exp Biol 202:2567-2580 
Podrabsky JE, Hrbek T, Hand SC (1998) Physical and chemical characteristics of ephemeral pond habitats in the Maracaibo basin and Llanos region of Venezuela. Hydrobiologia 362:67-78

Podrabsky JE, Lopez JP, Fan TWM, Higashi R, Somero GN (2007) Extreme anoxia tolerance in embryos of the annual killifish Austrofundulus limnaeus: Insights from a metabolomics analysis. J Exp Biol 210:2253-2266

Podrabsky JE, Riggs CL, Duerr JM (2012) Anoxia Tolerance During Vertebrate Development - Insights from Studies on the Annual Killifish Austrofundulus limnaeus. In: Padilla P (ed) Anoxia. InTech, pp 3-24

Rombough PJ (1988a) Growth, aerobic metabolism, and dissolved oxygen requirements of embryos and alevins of steelhead, Salmo gairdneri. Can J Zool 66:651-660

Rombough PJ (1988b) Respiratory gas exchange, aerobic metabolism, and effects of hypoxia during early life. Fish Physiol 11A:59-161

Shang EHH, Wu RSS (2004) Aquatic Hypoxia Is a Teratogen and Affects Fish Embryonic Development. Environ Sci Tech 38:4763-4767

Sloper JJ, Johnson P, Powell TPS (1980) Selective degeneration of interneurons in the motor cortex of infant monkeys following controlled hypoxia: a possible cause of epilepsy. Brain Res 198:204-209

Spoor WA (1977) Oxygen requirements of embryos and larvae of the largemouth bass, Micropterus salmoides (Lacepede). J Fish Biol 11:77-86

Wourms JP (1972) The developmental biology of annual fishes III. Preembryonic and embryonic diapause of variable duration in the eggs of annual fishes. J Exp Zool 182:389-414 